\title{
Review Article \\ Research and Development Aspects on Chemical Preparation Techniques of Photoanodes for Dye Sensitized Solar Cells
}

\author{
Nilofar Asim, ${ }^{1}$ Shideh Ahmadi, ${ }^{2}$ M. A. Alghoul, ${ }^{1}$ F. Y. Hammadi, ${ }^{1}$ \\ Kasra Saeedfar, ${ }^{3,4}$ and K. Sopian ${ }^{1}$ \\ ${ }^{1}$ Solar Energy Research Institute, Universiti Kebangsaan Malaysia, 43600 Bangi, Selangor, Malaysia \\ ${ }^{2}$ NOVITAS, School of Electrical and Electronic Engineering, Nanyang Technological University, Singapore 639798 \\ ${ }^{3}$ School of Chemical Science \& Food Technology, Faculty of Science and Technology, Universiti Kebangsaan Malaysia, \\ 43600 Bangi, Selangor, Malaysia \\ ${ }^{4}$ Department of Chemistry, Faculty of Science, K. N. Toosi University of Technology, Tehran, Iran
}

Correspondence should be addressed to Nilofar Asim; asimnilofar@gmail.com and M. A. Alghoul; dr.alghoul@gmail.com

Received 5 August 2013; Revised 19 November 2013; Accepted 21 November 2013; Published 12 January 2014

Academic Editor: Mahmoud M. El-Nahass

Copyright (C) 2014 Nilofar Asim et al. This is an open access article distributed under the Creative Commons Attribution License, which permits unrestricted use, distribution, and reproduction in any medium, provided the original work is properly cited.

The importance of dye sensitized solar cells (DSSCs) as a low-cost and environmentally friendly photovoltaic (PV) technology has prompted many researchers to improve its efficiency and durability. The realization of these goals is impossible without taking into account the importance of the materials in DSSCs, so the focus on the preparation/deposition methods is essential. These methods can be either chemical or physical. In this study, the chemical applied methods that utilize chemical reaction to synthesize and deposit the materials are covered and categorized according to their gas phase and liquid phase precursors. Film processing techniques that can be used to enhance the materials' properties postpreparation are also included for further evaluation in this study. However, there is a variety of consideration, and certain criteria must be taken into account when selecting a specific deposition method, due to the fact that the fabrication conditions vary and are unoptimized.

\section{Introduction}

Dye sensitized solar cells (DSSCs) as a novel photovoltaic (PV) technology have the potential to compete with other traditional solar cell because they are low-cost and an environmental friendly solar cell. Their low weight, flexibility, transparency, varied color, and superior performance in darker conditions make them more popular and have attracted considerable company investment and government funding.

The power conversion efficiency of a DSSC is highly reliant on its materials, which puts them at the forefront of research. However, it is not alone in its importance, as other areas are equally crucial in the quest to realize a stable, efficient, and low-cost dye sensitized solar cells [1-3].

Although there are many interesting research findings based on the development of nanomaterial and new hybrid materials $[4,5]$, there is still room for progress and the solving of different issues dealing with dye sensitized solar cells. The preparation and deposition methods are critical vis-à-vis the properties of DSSC.

Weerasinghe et al. [6] have reviewed the technological development of DSSC on flexible polymer substrates, paying attention to factors that are imperative to the preparation of the slurry, film deposition, and electrode processing intended to enhance the mechanical and photovoltaic properties of a device.

The aim of this review is to demonstrate the different preparation and deposition methods, which have been used in DSSC, emphasizing their advantages and disadvantages, in order to allow a researcher to carefully choose and optimize a given method. Chemical methods are further categorized according to their reaction medium or precursors, such as gas and liquid. We tried to categorize these methods by considering this concept, although overlapping does occur from time to time. 


\section{Gas Phase Precursors}

2.1. Chemical Vapor Deposition (CVD). The process that is called chemical vapor deposition (CVD) of films and coatings is the result of chemical reactions that occur between the gaseous reactant close to or adjacent to the surface of a heated substrate (Figure 1). The flexible nature of CVD makes it one of the preferred methods of thin film deposition and coatings. The applications of CVD coated thin films are, but not limited to, semiconductors for microelectronics; optoelectronics, energy conversion devices; dielectrics for microelectronics; refractory ceramic materials for hard coatings, corrosion protection, oxidation, or as diffusion barriers; metallic films for microelectronics and for protective coatings; and fiber production and coating [7].

2.1.1. Advantages and Disadvantages of CVD. On top of its complex chemical system, some of the advantages of CVDs are [7] as follows.

(a) Being able to produce extremely dense and pure materials and allowing manipulation at the atomic or nanometer scales.

(b) The films are highly uniform and have good reproducibility and adhesion, with acceptable deposition rates.

(c) Due to its good throwing power and nonline of sight nature, it can be used to uniformly coat complexshaped components and deposit films with reasonable conformal coverage, which is significantly advantageous compared to the physical vapor deposition (PVD) processes.

(d) Properties such as crystal structure, surface morphology, and orientation of the products can be manipulated and customized via the CVD's process parameters.

(e) It is capable of producing a variety of coatings, such as single layer, multilayer, composite, nanostructured, and functionally graded coating materials, along with well-controlled dimension and unique structure at low processing temperatures.

(f) The rate of deposition can be readily adjusted. Low deposition rates are favored for the growth of epitaxial thin films for microelectronic applications, while high deposition rates are preferred for the deposition of thick protective coatings.

(g) The processing cost for the conventional CVD technique is quite low.

(h) The CVD technique allows the usage of a wide variety of chemical precursors, such as halides, hydrides, and organometallics, which enables the deposition of a large spectrum of materials that encompasses metals, carbides, nitrides, oxides, sulphides, III-V, and II-VI materials.

(i) The low deposition temperatures allow the desired phases to be deposited in-situ at low energies via

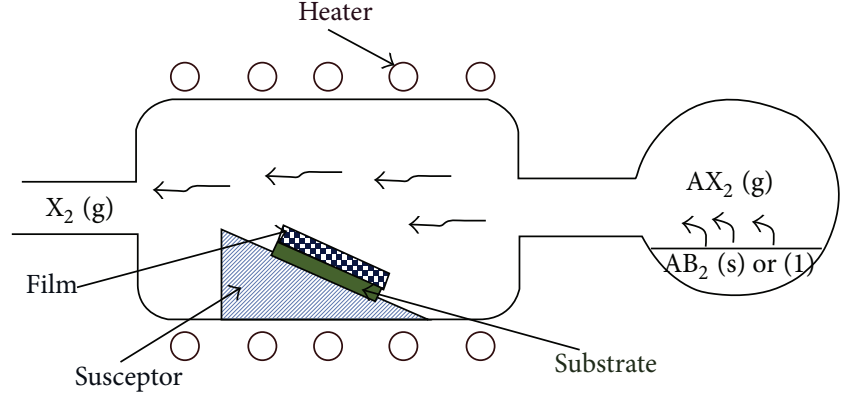

Figure 1: A schematic diagram of the CVD coating [7].

vapor phase reactions, or nucleation and growth on the substrate's surface. This, in turn, allows the deposition of refractory materials at a fraction of their respective melting temperatures.

However, the drawbacks of this technique include the following:

(a) the inherent chemical and safety hazards that might be instigated by the use of toxic, corrosive, flammable, and/or explosive precursor gases. Recently however, these issues have been mitigated by using variants of CVD methods such as electrostatic spray-assisted vapor deposition (ESAVD) and combustion chemical vapor deposition (CCVD) methods, which employ more environmental-friendly precursors;

(b) the difficulty encountered when trying to deposit multicomponent materials with well-controlled stoichiometry via multisource precursors, due to the fact that different precursors adhere to different vaporization rates. However, this limitation can be negated via the utilization of single source chemical precursors;

(c) the high level of sophistication in the reactor or vacuum system in CVD variants such as low pressure or ultrahigh vacuum CVD, plasma-assisted CVD, and photo-assisted CVD tends will inevitably increase the cost of production. However, there are exceptions to this case, such as aerosol assisted chemical vapor deposition (AACVD) and flame-assisted chemical vapor deposition (FACVD), where it might be a viable alternative that guarantees low production costs [7].

2.1.2. Variants of CVD Methods. Both the conventional CVD and thermal activated CVD (TACVD) rely upon thermal energy to activate chemical reactions. However, other sources of energy are also viable for this purpose. The advancements and uniqueness of different variants of the CVD method are discussed and detailed by Choy [7], while Figure 2 represents the relationship between different parameters and coating properties.

In all of the CVD processes, several basic functions must be provided. This includes free movement of the reactants and diluents gases to the deposition surface, utilizing different source to provide reactant's activation energy, and maintain 


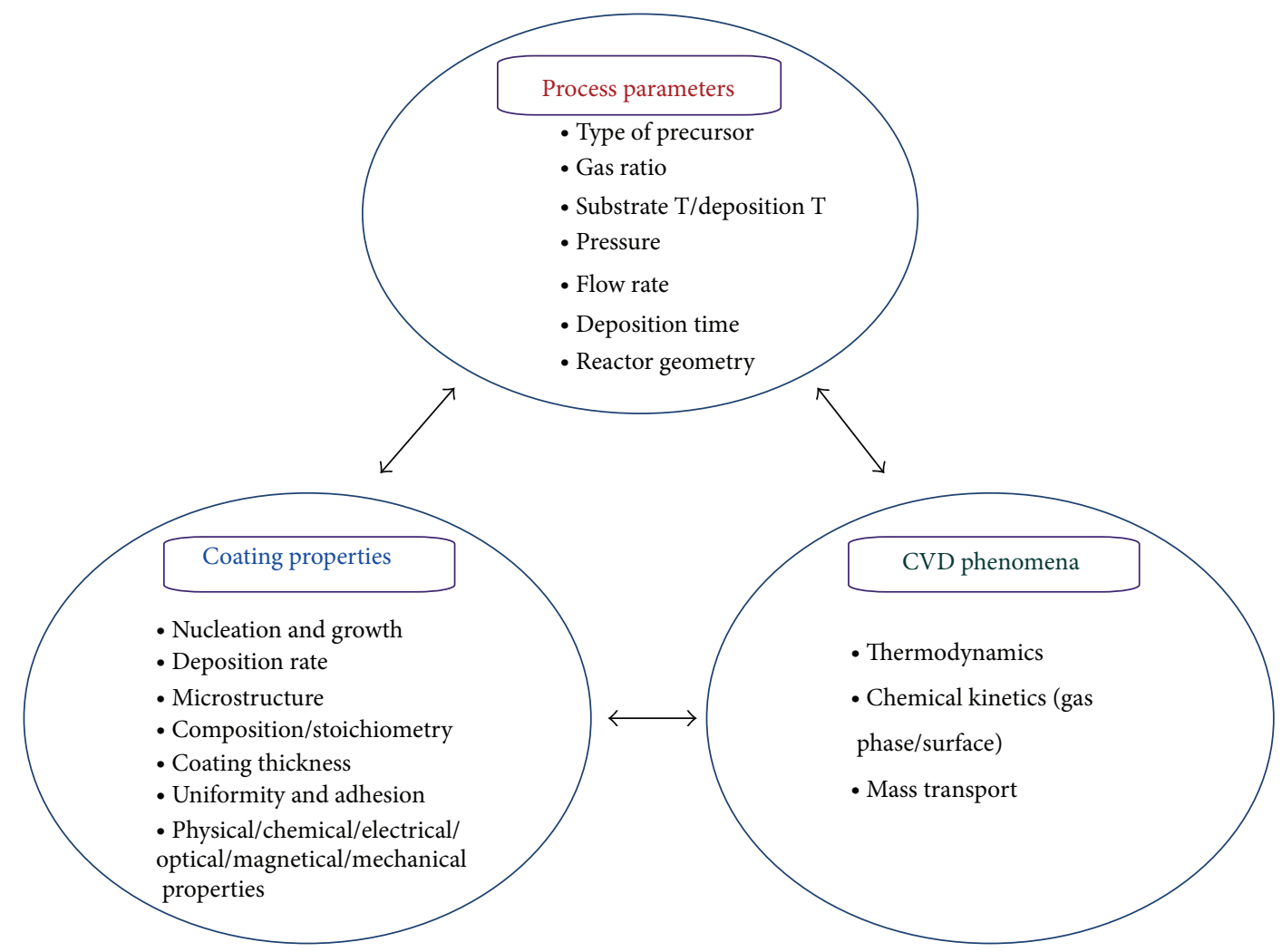

FIgURE 2: A schematic representation of the relationship of process parameters, CVD phenomena, and coating properties [7].

a specific system pressure and temperature, optimizing the chemical deposition method, and the complete removal of by-product gases. The provisions of these functions, however, require adequate control, high effectiveness, and foolproof safety.

Atmospheric-pressure CVD (APCVD) uses the lowtemperature (below $600^{\circ} \mathrm{C}$ ) rotary vertical-flow reactors and a continuous, in-line conveyorized reactors with various gas distribution features, mostly for depositing oxides, binary and ternary silicate glass coatings for solid-state devices. Lowpressure CVD (LPCVD) (typically 0.1-10 torr) in the low-, mid-, or high-temperature range uses resistance-heated hotwall reactors of tubular, bell-jar, or close-spaced designs. The advantage and wide usage of LPCVD over APCVD are attributed to the fact that, in LPCVD, no carrier gases are needed, particle contamination is reduced, and film uniformity and conformity are superior in conventional APCVD reactor systems [8].

In a metalorganic chemical vapor deposition (MOCVD), the copyrolysis of various combinations of organometallic compounds and hydrides is employed for the growth of thin epitaxial layers of compound semiconducting materials. Composite layers of accurately controlled thickness and dopant profile are required to produce structures of optimal designs for device fabrication [9].

Photo-enhanced chemical vapor deposition (PHCVD) uses electromagnetic radiation, usually short-wave ultraviolet radiation in order to activate the reactants in the gas or vapor phase. The selective absorption of photonic energy by the reactant molecules or atoms initiates the process by forming reactive free-radical species that will then interact to form a desired film product. In laser-induced chemical vapor deposition (LCVD), a laser beam prepares a highly localized heat in a substrate, which will then induce film deposition via CVD surface reactions [8]. Table 1 presents some of research results on materials' preparation using CVD methods for DSSC application.

2.2. Atomic Layer Deposition (ALD). The atomic layer deposition (ALD) method is considered a self-imposed film growth method that is defined by the alternating exposure of the chemical species in a layer-by-layer manner. ALD is divided into four crucial steps: (1) the exposure of the metal precursor, (2) evacuation or purging of the precursors and any by products from the chamber, (3) exposure of the other reactant species (nonmetal precursor), for example, nitrogen containing reducing agents for nitrides or reducing agents for metals, and (4) evacuation or purging of the reactants and by product molecules from the chamber (Figure 3). The most imperative requirement in the initial step is self-imposed limitation on the precursor molecule's adsorption process. In most cases, this requirement is met via the ligands that are linked to the metal atoms present in the precursors, which includes halogen or organic ligands. This will inevitably curtail further adsorption by the metal precursor via the passivation of the adsorption sites on the saturation coverage of one monolayer or less 
TABLE 1: Some research results on DSSC using different CVD methods.

\begin{tabular}{|c|c|c|c|}
\hline Materials & Method & Efficiency $(\eta) \%$ & Reference \\
\hline $\begin{array}{l}\text { Graphene-based multiwalled carbon } \\
\text { nanotubes (GMWNTs) }\end{array}$ & $\begin{array}{l}\text { Drop casting and low pressure chemical vapor } \\
\text { deposition (LPCVD) }\end{array}$ & 3.0 & {$[130]$} \\
\hline Nanostructured $\mathrm{TiO}_{2}$ & Flat-flame chemical vapor deposition & $>4$ & {$[131]$} \\
\hline Graphene-CoS & $\begin{array}{l}\text { Low pressure thermal chemical vapor } \\
\text { deposition (LPCVD) }\end{array}$ & 3.42 & {$[78]$} \\
\hline $\mathrm{ZnO} / \mathrm{TiO}_{2}$ & Thermal chemical vapor deposition & - & {$[132]$} \\
\hline $\begin{array}{l}\mathrm{ZnO} \text { nanostructures coated on vertically } \\
\text { aligned carbon nanotubes (CNTs) }\end{array}$ & Thermal chemical vapor deposition & 1.94 & {$[133]$} \\
\hline MWNTs (multiwall carbon nanotubes) & Thermal chemical vapor deposition & 0.99 & {$[134]$} \\
\hline $\mathrm{TiO}_{2}$ thin film & $\begin{array}{l}\text { Metalorganic chemical vapor deposition } \\
\text { (MOCVD) }\end{array}$ & - & {$[135]$} \\
\hline $\begin{array}{l}\text { InN deposited over } \mathrm{TiO}_{2} \text { nanoparticle } \\
\text { (NP) films }\end{array}$ & $\begin{array}{l}\text { Metalorganic chemical vapor deposition } \\
\text { (MOCVD) }\end{array}$ & 7.07 & {$[136]$} \\
\hline $\begin{array}{l}\text { Mesoporous } \mathrm{TiO}_{2} \text { with polymer } \\
\text { electrolyte }\end{array}$ & Initiated chemical vapor deposition (iCVD) & 2.8 & {$[137]$} \\
\hline $\mathrm{TiO}_{2}$ thin films & $\begin{array}{l}\text { Atmospheric pressure chemical vapor } \\
\text { deposition (APCVD) }\end{array}$ & - & {$[138]$} \\
\hline Nanocrystalline $\mathrm{TiO}_{2}$ thin films & Chemical vapor deposition & 0.17 & [139] \\
\hline
\end{tabular}

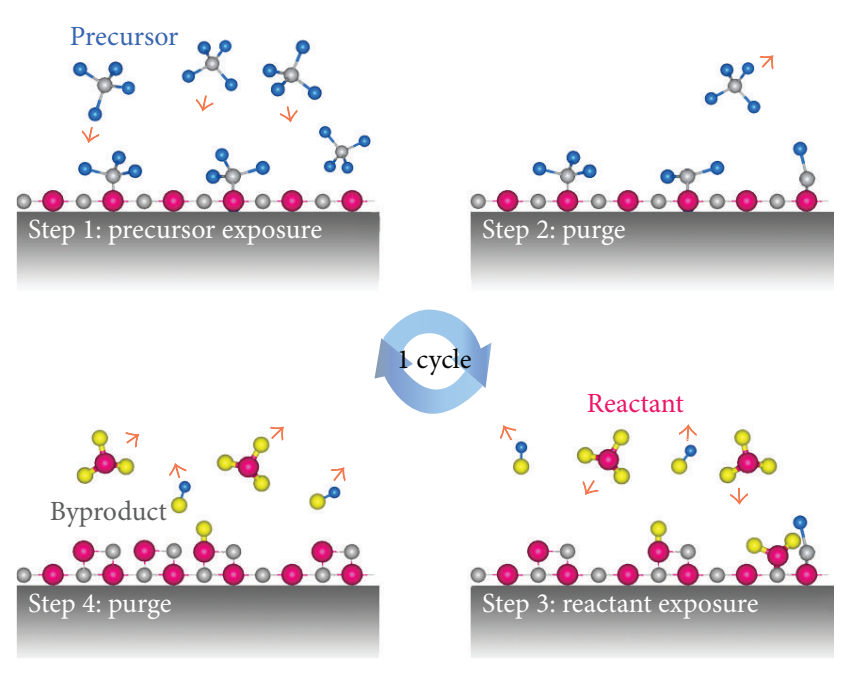

Figure 3: Atomic layer deposition (ALD) [10].

that is achieved. The current trend of downscaling devices has propelled ALD to the forefront as one of the primary methods of nanoscale device fabrication, due to its superiority over conventional techniques such as PVD or CVD.

2.2.1. Advantages and Limitations. ALD is sequential, selflimiting surface reaction process that enables atomic layer control (angstrom or monolayer level) and excellent conformal deposition [11]. This aspect results in excellent step coverage and conformal deposition on high aspect ratio structures. ADL can produce continuous, smooth, and pinhole-free film. It is possible to obtain high quality materials and low processing temperatures with the ALD method.

ALD processing also includes enormous substrates and parallel processing of multiple substrates as well. Due to the fact that the precursors to the ALD are gas phase molecules, the entire space will be filled with it regardless of the substrate's geometry. The line-of-sight to the substrate vis-àvis the substrate in this process is also unimportant, along with problems such as unpredictable vaporization rates of solid precursors. ALD possesses excellent reproducibility and is capable of producing multilayer structures in a continuous process $[12,13]$. ALD is also capable of producing sharp interfaces and superlattices, allowing for the possibility of interface modification.

One major limitation of the ALD method is its lack of speed, resulting in only a fraction of a monolayer being deposited in a single cycle. However, the recent developments help the commercial ALD tools in realizing cycle times of $<5$ seconds, resulting in the deposition of a $100 \mathrm{~nm}$ film in less than an hour. Recent advances in roll-to-roll ALD are allowing for an even faster throughput.

The materials for the films grown by ALD are numerous, which also includes technologically strategic materials such as $\mathrm{Si}, \mathrm{Ge}$, and $\mathrm{Si}_{3} \mathrm{~N}_{4}$. However, certain multicomponent oxides and metals cannot be grown or deposited by ALD in an economical manner, which renders their deposition unfeasible.

Another limitation of ALD is that it is confined by the size of its reaction chamber. In addition, due to the fact that it is a chemical technique, there is always a chance that chemical residues from the precursor might remain in the chamber. Table 2 presents the results of DSSC prepared using ALD methods. 
TABLE 2: Results of DSSC using ALD method.

\begin{tabular}{lccc}
\hline Materials & Method & Efficiency $(\eta) \%$ & Reference \\
\hline $\mathrm{Al}_{2} \mathrm{O}_{3}$-coated $\mathrm{TiO}_{2}$ (core-shell) & Atomic layer deposition (ALD) & 8.4 \\
$\begin{array}{l}\text { Hafnium oxide }\left(\mathrm{HfO}_{2}\right) \text { and aluminum } \\
\text { oxide }\left(\mathrm{Al}_{2} \mathrm{O}_{3} \text { ) on mesoporous } \mathrm{TiO}_{2}\right.\end{array}$ & Atomic layer deposition (ALD) & 7.1 \\
$\mathrm{Al}_{2} \mathrm{O}_{3}$ overlayers on porous $\mathrm{TiO}_{2}$ & Atomic layer deposition (ALD) & - \\
$\mathrm{Highly}$ ordered and vertically oriented & $\begin{array}{c}\text { Template-assisted method using atomic layer } \\
\text { deposition (ALD) and reactive ion etching (RIE) }\end{array}$ & {$[141]$} \\
$\mathrm{TiO}_{2}$ nanotube arrays & & {$[142]$}
\end{tabular}

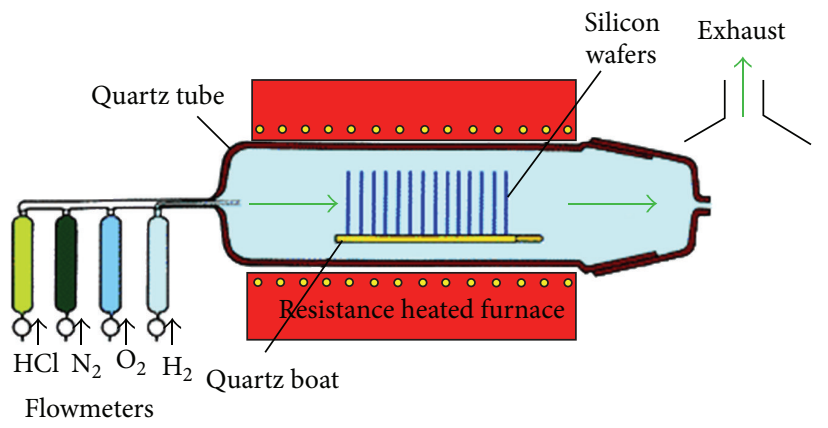

FIgURE 4: Schematic of a thermal oxidation furnace [14].

2.3. Thermal Oxidation. The method of thermal oxidation produces a thin layer of oxide on a wafer's surface. It forces the diffusion of an oxidizing agent into the wafer at high temperatures and induces a reaction within it. The DealGrove model predicts the rate the oxide growth. Figure 4 shows a thermal oxidation furnace.

$\mathrm{ZnO}$ nanobelts and nanotetrapods are fabricated via the thermal oxidation reaction technique. The process begins by heating the zinc paste that was prepared from zinc powder (purity 99.9\%), which was then mixed with a hydrogen peroxide solution (30 wt.\%) at a temperature of $1000^{\circ} \mathrm{C}$ under normal atmosphere for a few minutes. The best results of DSSCs were the short circuit current $\left(J_{\mathrm{sc}}\right)$ of $1.25 \mathrm{~mA} / \mathrm{cm}^{2}$, the open circuit voltage $\left(V_{\text {oc }}\right)$ of $0.45 \mathrm{~V}$, a fill factor $(\mathrm{FF})$ of $0.65 \%$, and the overall energy conversion efficiency $(\eta)$ of $0.68 \%[15]$.

$\mathrm{ZnO}$ nanonetwork structures with high porosities were fabricated for use in the photoelectrodes of binder-free dyesensitized solar cells (DSSCs) by the PVD method of DC sputtering, followed by thermal oxidation. The nano-network of $\mathrm{Zn}$ was successfully transformed into $\mathrm{ZnO}$ without undergoing a morphological change through annealing in open atmosphere [16].

Moreover, $\mathrm{Ti}-\mathrm{TiO}_{2}$ structure has been used in the fabrication of numerous $\mathrm{TiO}_{2}$-based devices, such as solar cells, electrocatalytic electrodes, and noble metal- $\mathrm{TiO}_{2}-\mathrm{Ti}$ chemical sensors. Hossein-Babaei and Rahbarpour [17] fabricated Ti$\mathrm{TiO}_{2}-\mathrm{Ti}$ and $\mathrm{Ag}-\mathrm{TiO}_{2}-\mathrm{Ti}$ structures on a thermally oxidized titanium chip and analyzed their electronic behaviors at different biasing, thermal, and atmospheric conditions.

\section{Liquid Phase Precursor}

Due to the fact that the liquid phase chemical methods are considered a bottom-up approach, the morphology of nanomaterials in the thin film can be tuned in order to allow for better control of particle size, shape, size distribution, particle composition, and degree of particle agglomeration, while the chemical deposition methods are inexpensive, which allows the synthesis of thin films materials containing complex chemical compositions. Lokhande et al. [18] investigated the deposition of nanocrystalline metal oxide thin films, using chemical methods, and the relation of their respective morphology in their various applications.

3.1. Electrochemical Deposition (ECD). The electrochemical deposition of metals and alloys revolves around the reduction of metal ions from aqueous, organic, and fused-salt electrolytes (see Figure 5). This process is represented by (1)

$$
\mathrm{M}^{z+}{ }_{\text {solution }}+z \mathrm{e} \longrightarrow \mathrm{M}_{\text {lattice }}
$$

This is achievable via two different processes: (1) an electrodeposition process, where $z$ electrons (e) are provided by an external power supply, and (2) an electroless (autocatalytic) deposition process, where a reducing agent in the solution is the electron source (sans an external power supply). Both processes are representative of electrochemical deposition [19].

The electrochemical method counts among the simplest and most effective method of fabricating 1D semiconductor nanostructures. Among variants of the electrochemical method in preparing oriented $1 \mathrm{D}$ film are template-assisted electrochemical synthesis and direct electrochemical growth via capping reagents [20]. Among the advantages of the electrochemical methods is the ability to customize and control the compositions and morphologies of nanostructured materials. Different types of electrochemical deposition such as electroplating, electrolytic anodization, and electrophoretic deposition can be used for the synthesis of materials. In Electrophoretic Deposition, dissociated colloidal cations and anions disperses onto a conductive substrate. After applying an electric field, the colloidal charged particles migrate to the substrate, get discharged, and form a film. Similar to thermal oxidation in Electrolytic anodization, an oxide film is formed on the substrate; the difference is that the anode is oxidized because of the negative ions in the electrolyte and forms a nonporous and well-adhering oxide or a hydrated 


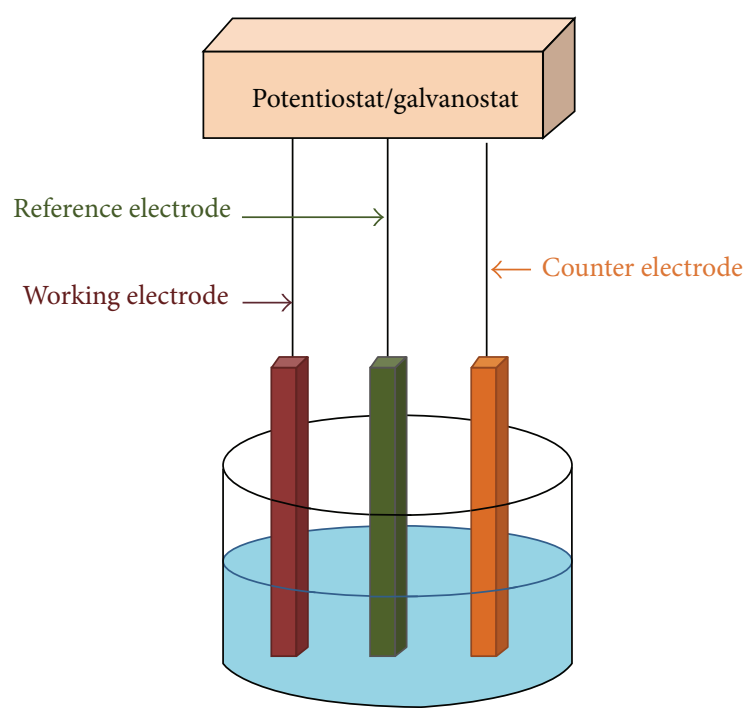

FIgURE 5: The schematic representation of the electrodeposition system [21].

oxide coating on semiconductors and on a few specific metals. During oxidation, the hydrogen gas evolves at the cathode. Electroplating can be used for the deposition of metallic coatings on the cathode's substrate when applying an electrical current to an electrolytic cell consisting of an anode, cathode, and an electrolyte solution (containing the metal ions) [8]. Table 3 summarizes the different type of electrochemical synthesis that is employed for DSSC.

3.2. Solvothermal/Hydrothermal Methods. Both the solvothermal and hydrothermal methods are effective tools in the generalization and systematic control of the syntheses of nanomorphologies. Figure 6 shows the typical autoclave for solvothermal/hydrothermal synthesis.

The solvothermal/hydrothermal methods are important technologies with regard to the production of semiconductor nanowires at low temperatures. Zou et al. [22] discussed nanowire growth from mainly four aspects in the solvothermal/hydrothermal processes (1) materials with highly anisotropic crystal structures, (2) coordination directing/mixed solvents, (3) surfactants/capping reagents, and (4) reactions at relatively high temperatures.

Both the hydrothermal and solvothermal methods have some poignant differences. These differences include the fact that the solvothermal method (using non-water as a solvent) can practically halt oxidization, a factor that is especially imperative to the synthesis of a variety of nonoxides [22].

"Hydrothermal synthesis" is defined by the heterogeneous reactions in aqueous media above $100^{\circ} \mathrm{C}$, at 1 bar of pressure [24]. It remains one of the preferred methods in fabricating pure fine oxide powders. Figure 7 details the schematic of the hydrothermal synthesis.

For hydrothermal experiments, the prerequisites for the starting materials are (i) knowing the composition, (ii) being as homogeneous as possible, (iii) being as pure as possible, and (iv) being as fine as possible [26]. Sōmiya and Roy [26]

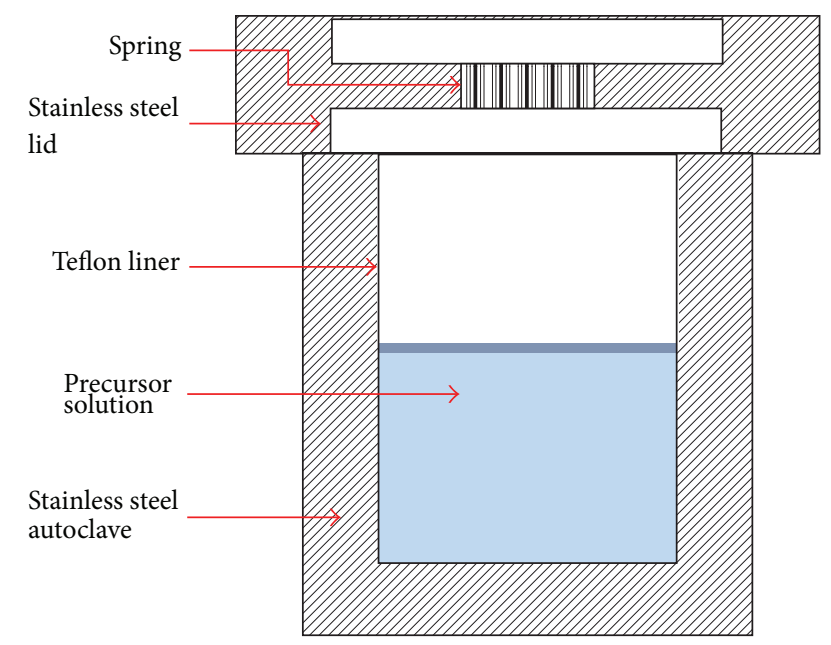

FIgURE 6: Schematic diagram of the autoclave used in solvothermal/hydrothermal synthesis [23].

described some of different types of hydrothermal synthesis methods (see Table 4).

3.2.1. Advantages and Disadvantages of Hydrothermal/Solvothermal Synthesis. The advantages include the following.

(1) Most of the materials that are involved can be induced to solubility via heat and pressure applied to the system up to its critical point.

(2) It offers a significant enhancement to the chemical activities of the reactant, the possibility to replace the solid-state synthesis, and materials, which may not be obtained via solid-state reaction but may be prepared through hydrothermal/solvothermal synthesis.

(3) Products of intermediate state, metastable state and specific phase may be easily produced, and novel compounds of metastable state and other specific condensed state may be synthesized.

(4) Simplified and precise control of the size, shape distribution, and crystallinity of the end product via the adjustment of parameters such as reaction temperatures and time, the types of solvents, surfactants and precursors can be achieved.

(5) Substances that are low in melting points and high in vapor pressures and tendency towards pyrolysis will be obtained.

The disadvantages of hydrothermal/solvothermal synthesis are as follows:

(1) the need of expensive autoclaves;

(2) safety issues during the reaction process;

(3) impossibility of observing the reaction process ("black box") [27].

Researchers have used both the hydrothermal and solvothermal methods extensively. Some of most recent researches 
TABLE 3: Different electrochemical deposition methods used in DSSC.

\begin{tabular}{|c|c|c|c|}
\hline Materials & Method & Efficiency $(\eta) \%$ & Reference \\
\hline $\begin{array}{l}\text { Porous } \mathrm{ZnO} \text { on carbon nanotube }(\mathrm{CNT}) \\
\text { coated polymer }\end{array}$ & Electrochemical deposition & 2.5 & {$[144]$} \\
\hline Vertical $\mathrm{ZnO}$ nanotube (ZNT) & $\begin{array}{l}\text { Electrochemical deposition followed by a selective } \\
\text { etching process }\end{array}$ & 1.01 & {$[145]$} \\
\hline $\begin{array}{l}\text { Well-crystallined } \mathrm{ZnO} \text {-eosin Y hybrid thin } \\
\text { films }\end{array}$ & Two-step cathodic electrodeposition & 0.21 & {$[146]$} \\
\hline Crystalline nanoporous layers of $\mathrm{ZnO}$ & Gas template electrodeposition & 2.1 & {$[147]$} \\
\hline $\mathrm{ZnO}$ /dye hybrid thin films & $\begin{array}{l}\text { Cathodic electrodeposition (electrochemically } \\
\text { self-assembled) }\end{array}$ & - & {$[148]$} \\
\hline $\mathrm{ZnO}$ nanobelt array films & $\begin{array}{l}\text { Electrodeposition method with liquid crystal } \\
\text { template }\end{array}$ & 2.6 & [149] \\
\hline $\mathrm{ZnO}$ porous film on a plastic substrate & $\begin{array}{l}\text { Electrophoresis deposition (EPD) process with } \\
\text { UV-O }_{3} \text { treatment }\end{array}$ & 4.04 & {$[150]$} \\
\hline $\mathrm{ZnO}$ photoanode on plastic & Electrophoretic deposition method & 4.17 & {$[151]$} \\
\hline $\begin{array}{l}\text { Nanowires and hierarchical } \mathrm{ZnO} \\
\text { nanostructures }\end{array}$ & $\begin{array}{l}\text { Anodization and subsequent electrochemical } \\
\text { deposition }\end{array}$ & - & {$[152]$} \\
\hline Branched hierarchical $\mathrm{ZnO}$ nanowire arrays & Two-step electrochemical deposition process & 0.88 & {$[153]$} \\
\hline Mesoporous platinum & Electrochemical deposition & 7.6 & {$[154]$} \\
\hline Platinum/graphene hybrid film & Electrochemical deposition & 7.88 & {$[155]$} \\
\hline Graphene-Pt/ITO (ITO-PG) & Electrochemical deposition & 7.57 & {$[156]$} \\
\hline Platinum nanoparticle & Electrochemical deposition & 6.4 & {$[157]$} \\
\hline Thin Pt counter electrode & Pulsed electrodeposition method & 6 & {$[158]$} \\
\hline Platinum nanoparticles on plastic substrates & Electrophoretic deposition & 5.8 & {$[159]$} \\
\hline Platinum (Pt) layer on ITO & Electroless deposition & 6.46 & {$[160]$} \\
\hline Composite (PProDOT-Et2/Pt) & Electropolymerization & 6.65 & {$[161]$} \\
\hline Closely packed titania nanoparticles & Electrochemical deposition & 6.27 & {$[162]$} \\
\hline Coaxial $\mathrm{TiO}_{2} / \mathrm{ZnO}$ nanotube arrays & Electrochemical deposition & 2.8 & {$[163]$} \\
\hline$\left(\mathrm{ClO}_{4}^{-}-\mathrm{PEDOT} / \mathrm{TiO}_{2} / \mathrm{FTO}\right)$ & Electrochemical deposition & 4.78 & {$[164]$} \\
\hline Nanocrystalline anatase $\mathrm{TiO}_{2}$ & Reductive electrodeposition & 5.1 & {$[165]$} \\
\hline $\mathrm{TiO}_{2} /$ dye hybrid films & Anodic electrodeposition & - & {$[166]$} \\
\hline Ordered titanate nanotube (TNT) films & Electrophoretic deposition & 3.79 & {$[167]$} \\
\hline Titanate nanotubes & Hydrothermal process and electrophoretic deposition & 6.71 & [168] \\
\hline Mesoporous $\mathrm{TiO}_{2}$ film on a titanium (Ti) foil & Electrophoretic deposition & 6.5 & [169] \\
\hline $\begin{array}{l}\text { Mesoporous } \mathrm{TiO}_{2} \text { photoanode film on } \\
\text { plastic substrate }\end{array}$ & Electrophoretic deposition & 4.37 & {$[170]$} \\
\hline $\mathrm{TiO}_{2}-\mathrm{B}$ nanoribbon films & Electrophoretic deposition & 0.87 & {$[171]$} \\
\hline Highly ordered $\mathrm{TiO}_{2}$ nanotube arrays & Electrophoretic deposition & 6.28 & {$[172]$} \\
\hline Titanium oxide $\left(\mathrm{TiO}_{x}\right)$ thin films & Cathodic electrolysis & 2.33 & {$[173]$} \\
\hline Nanostructured $\mathrm{TiO}_{2}$ films & $\begin{array}{l}\text { Plasma electrolytic oxidation combined with } \\
\text { chemical and thermal post-treatments }\end{array}$ & 2.194 & {$[174]$} \\
\hline $\begin{array}{l}\text { Combined } \mathrm{TiO}_{2} \text { structure with nanotubes } \\
\text { and nanoparticles }\end{array}$ & Electrochemical anodization & 5.75 & {$[175]$} \\
\hline Titanium dioxide $\left(\mathrm{TiO}_{2}\right)$ nanotube arrays & Anodizing & 4.38 & {$[176]$} \\
\hline Non-annealed anatase $\mathrm{TiO}_{2}$ film & Anodizing and sputtering & - & {$[177]$} \\
\hline Titania nanotube arrays & Electrochemical anodization & - & {$[178]$} \\
\hline $\mathrm{TiO}_{2}$ nanotube arrays & Anodizing, detachment and transfer method & 1.78 & {$[179]$} \\
\hline $\begin{array}{l}\text { Aligned high-aspect ratio } \mathrm{TiO}_{2} \text { nanotube } \\
\text { bundles }\end{array}$ & Rapid breakdown anodizing (electrochemical) & - & {$[180]$} \\
\hline Well-aligned $\mathrm{TiO}_{2}$ nanotube arrays & Electrochemical etching & 2.13 & {$[181]$} \\
\hline
\end{tabular}


TABle 3: Continued.

\begin{tabular}{|c|c|c|c|}
\hline Materials & Method & Efficiency $(\eta) \%$ & Reference \\
\hline $\mathrm{TiO}_{2}$-nanotube array electrode & $\begin{array}{l}\text { Arc ion plating (AIP) deposition and anodically } \\
\text { oxidizing }\end{array}$ & 1.88 & {$[182]$} \\
\hline Nanocrystalline $\mathrm{TiO}_{2}$ films & $\begin{array}{l}\text { Microplasma oxidation (MPO) method (process } \\
\text { combines electrochemical oxidation with a } \\
\text { high-voltage spark treatment in an electrolyte bath) }\end{array}$ & 0.092 & [183] \\
\hline Nanostructured $\mathrm{TiO}_{2}$ films & $\begin{array}{l}\text { Plasma electrolytic oxidation (PEO)combined with } \\
\text { chemical and thermal posttreatments }\end{array}$ & 2.194 & {$[174]$} \\
\hline $\begin{array}{l}\text { Functionalized and nonfunctionalized } \\
\text { fullerene thin films on ITO glasses }\end{array}$ & $\begin{array}{l}\text { Electrolytic micelle disruption method (the } \\
\text { electrolysis method) }\end{array}$ & - & {$[184]$} \\
\hline $\begin{array}{l}\text { Arborous structure } \mathrm{SnO}_{2} \text { porous films on } \mathrm{Ti} \\
\text { substrate }\end{array}$ & Pulse-potential technique (electrodeposition) & 0.47 & {$[185]$} \\
\hline Crystalline CuSCN films & Cathodic electrodeposition & - & {$[186]$} \\
\hline (PProDOT-Et2) & $\begin{array}{l}\text { Electrochemical polymerization } \\
\text { (electropolymerization) }\end{array}$ & 7.88 & {$[187]$} \\
\hline $\begin{array}{l}\text { High conductive transparent substrates were } \\
\text { fabricated with nickel grids }\end{array}$ & Electroplating process & 4.3 & {$[188]$} \\
\hline Polyaniline nanofiber/carbon film & Electrochemical deposition & 6.85 & [189] \\
\hline Polyaniline nanofibers & Pulse electropolymerization & 5.13 & [190] \\
\hline
\end{tabular}

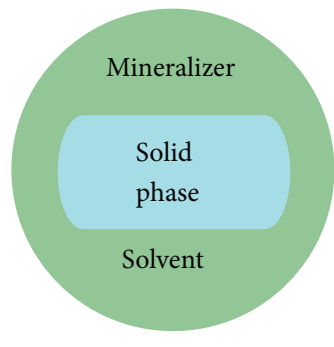

Starting materials
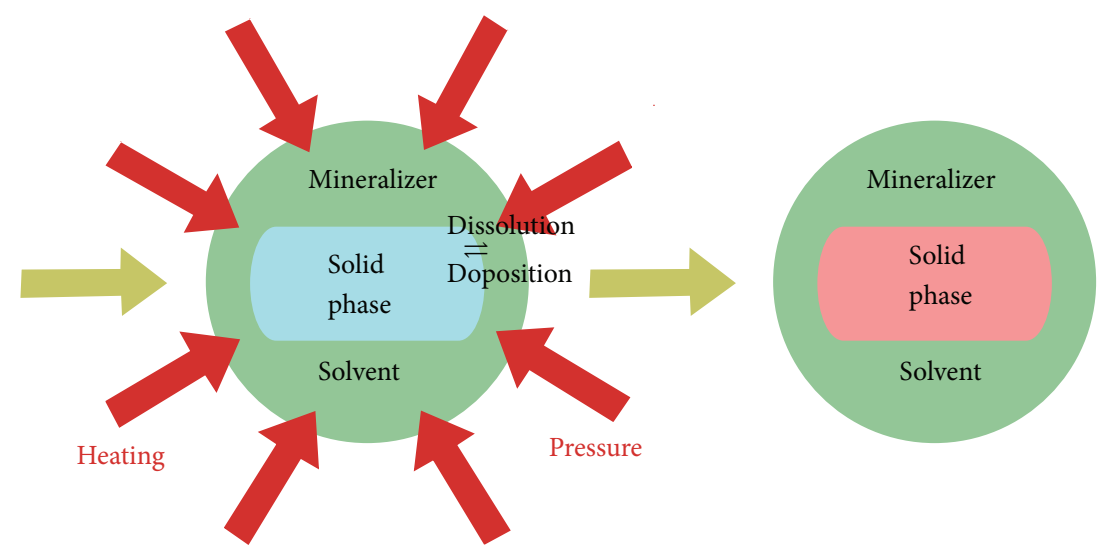

Figure 7: Schematic of the hydrothermal synthesis procedure [25].

[28-32] have used the hydrothermal method for the preparation of nanoparticles of $\mathrm{TiO}_{2}$ and $\mathrm{ZnO}$ and their composites for DSSC application. Feng et al. [33] employed the hydrothermal method, followed by a fast dip coating for the synthesis of $\mathrm{ZnO} @ \mathrm{TiO}_{2}$ core-shell long nanowire arrays. Their DSSC achieved an efficiency of 3.8. Other researchers used mix solvents for the hydrolysis of $\mathrm{TiCl}_{4}$. The experimental test of prepared DSSC from the resulted nanocrystalline $\mathrm{TiO}_{2}$ showed the high value efficiency $(\eta=$ 9.13\%) [34]. Capping agents-assisted hydrothermal method has been employed for the preparation of $\mathrm{ZnO}$ nanostructures for DSSC application [35]. The application of the solvothermal method using templates for the synthesis of mesoporous titania hollow spheres resulted in a DSSC with $3.16 \%$ efficiency.

3.2.2. Microwave Irradiation. The hydrothermal method plays a defining role in the shaping of the microstructures of $\mathrm{TiO}_{2}$. However, conventional hydrothermal processing is usually reliant upon high temperatures and pressures, along with extended processing times and complex procedures for the synthesis of $\mathrm{TiO}_{2}$ nanocrystals $[36,37]$. This paves the way for microwave processing of inorganic compounds, which forms an attractive field in modern material science. To this end, many inorganic materials had been synthesized via microwave ovens [38-42], mostly through rapid microwavematerial interactions. This technique is also viable for the synthesis of nanosized $\mathrm{TiO}_{2}$ powder possessing high degrees of crystallinity and monodispersed crystallites [43-45].

It has also been reported that the integration of microwave irradiation has effectively enhanced the efficiency of the hydrothermal method vis-à-vis the preparation of inorganic materials [46-53]. Microwave-assisted method has the unique advantage of uniform, rapid, and volumetric heating compared to its conventional counterpart. Moreover, microwave-assisted hydrothermal method significantly reduces both the processing time and temperatures, which 
TABLE 4: Hydrothermal synthesis.

\begin{tabular}{l}
\hline Hydrothermal crystal growth \\
Hydrothermal treatment \\
Hydrothermal alternation \\
Hydrothermal dehydration \\
Hydrothermal extraction \\
Hydrothermal reaction sintering \\
Hydrothermal sintering \\
Corrosion reaction \\
Hydrothermal oxidation \\
Hydrothermal precipitation-hydrothermal crystallization \\
Hydrothermal decomposition \\
Hydrothermal hydrolysis-hydrothermal precipitation \\
Hydrothermal electrochemical reaction \\
Hydrothermal mechanochemical reaction \\
Hydrothermal + ultrasonic \\
Hydrothermal + microwave
\end{tabular}

results in rapid crystallization and the simplification of the whole process [37]. In most cases, $\mathrm{TiO}_{2}$ nanoparticles are produced via the hydrothermal treatment. A multimode microwave heating system, operating at a frequency of $28 \mathrm{GHz}$, is utilized in order to induce rapid processing [45]. The synthesis of $\mathrm{ZnO}$ nanorods electrodes utilizing microwaves also demonstrated marked performance improvements [54].

It has been determined that the usage of organometallic or inorganic precursors in microwave-assisted methods resulted in remarkable improvements in all aspects. This is demonstrated in the work of Bhatte and coworkers [55], where they employed $\mathrm{Zn}\left(\mathrm{CH}_{3} \mathrm{COO}\right)_{2}$ as an additive-free synthesis of nanocrystalline zinc oxide via the microwave technique. Also, Brahma and Shivashankar [56] reported the utilization of the microwave method for depositing thin films and thick coatings of metal oxides via a liquid medium involving the microwave irradiation of an inorganic complex solution and zinc acetylacetonate in a dielectric solvent. In this work, $\mathrm{ZnO}$ nanoflowers and ZnGly micro- and nanoplates are synthesized via a very rapid and convenient microwaveassisted polyol method. $\mathrm{ZnO}$ nanoflower based solar cell sensitized with N719 dye demonstrated the maximum conversion efficiency of 1.03\% [57].

Meanwhile, it must be considered that microwave technique can be used with other methods such as chemical bath deposition, which requires heating and calcination.

3.2.3. Ultrasonic Technique. The method of sonochemical processing has proven itself useful in fabricating novel materials with unique properties $[58,59]$. The working principle behind the chemical effect of ultrasound is derived from acoustic cavitation, which is the formation, growth, and implosive collapse of bubbles in a liquid. This in turn generates localized hot spots via adiabatic compression or shock wave formation within the gas phase of the collapsing bubble. These formed hot spots are demonstrated to possess a transient temperature of about $5000 \mathrm{~K}$, pressure of $1800 \mathrm{~atm}$, and cooling rates exceeding $108 \mathrm{Ks}^{-1}$ [59]. The specific application of ultrasound in the synthesis of a variety of materials has been analyzed by Suslick and Price [60].

Wang et al. [61] employed ultrasonic waves to fabricate mesoporous $\mathrm{TiO}_{2}$ under different conditions for DSSC applications.

3.3. Chemical Bath Deposition (CBD). The chemical bath deposition (CBD) method, also known as controlled precipitation or solution growth method, or quite simply, chemical deposition, has recently been vaunted as a viable method for the deposition of both metal chalcogenide and metal oxide thin films. CBD is essentially a simple method, requiring only a hot plate with a magnetic stirrer. The precursor chemicals are widely available and cost little. The CBD method allows the coating of a large number of substrates in a single cycle, provided that a proper jig is designed to do so. In the context of this method, the electrical conductivity of the substrate is unimportant. Any part of the surface that is insoluble and can be accessed by the solution will make a suitable deposition substrate. The deposition process happens at low temperatures, which circumvents the occurrence of oxidation and corrosion of metallic substrates. Chemical deposition usually results in the absence of pinholes, and uniform deposits are easily obtained, since their basic building blocks are ions instead of atoms. The parameters are easily controlled, which allows us to gain better orientations and grain structures. The formation of the film occurs when the ionic product dominates the solubility product $[8,9]$. The whole setup of this process is detailed in Figure 8.

The chemical bath deposition (CBD) method has been employed for the preparation of nanostructures $\mathrm{ZnO}$ [62], garland like $\mathrm{ZnO}$ nanorods [63], nanobeads of zinc oxide [64], cauliflower-like ZnO Films [65], mesoporous F-doped $\mathrm{ZnO}$ prism array [66], $\mathrm{ZnO}$ nanorod arrays [67], $\mathrm{ZnO}$ nanocomposites [68], and $\mathrm{ZnO}$ nanoarray [69].

Zumeta et al. and Vigil et al. [50, 70] used microwaveactivated chemical-bath deposition (MW-CBD) for the preparation of $\mathrm{TiO}_{2}$ for DSSC. They claimed that the resulting $\mathrm{TiO}_{2}$ has superior electrical and mechanical properties.

PVP capped Pt nanoclusters on ITO glass and platinum on metallic sheets were both prepared using the chemical deposition method, and have been used in DSSC as counter electrodes [72, 73].

$\mathrm{Li}$ et al. [74] have synthesized $\mathrm{SrSnO}_{3}$ nanoparticles and employed them for the first time as electrode materials in DSSC using CBD. The prepared DSSC has achieved an efficiency of $1.02 \%$.

3.4. Successive Ionic Layer Adsorption and Reaction (SILAR) Method. Successive ionic layer adsorption and reaction (SILAR) is a recently developed method for the deposition of metal chalcogenide thin films, although it has undergone less scrutiny by researchers $[75,76]$. The method is based on the immersion of a substrate into anionic and cationic precursors, followed by rinsing of the substrate between every 


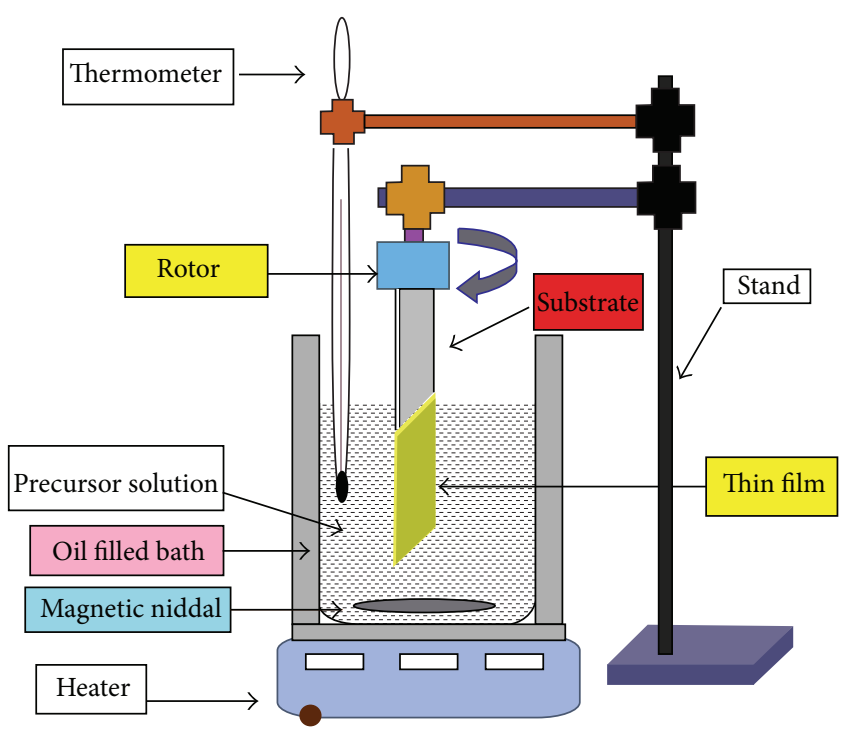

FIgURE 8: Schematic representation of chemical bath deposition method [71].

immersion in double distilled water in order to circumvent homogeneous precipitation. Figure 9 graphically summarizes this method. During the immersion into a cationic precursor, cations are adsorbed onto the substrate's surface. The act of rinsing after immersion will separate the unabsorbed or excess ions, while simultaneously preventing homogeneous precipitation. Similarly, when immersed in an anionic precursor solution, the anions will react with the preadsorbed cations. The remaining unreacted/powdery material can be expelled via rinsing. The whole process of immersion and rinsing in both the cationic and anionic precursor is regarded as one full cycle. After a few repetitions of these cycles, a multilayer film of desired thickness would be formed. The quality and thickness of these respective films are highly dependent on the preparation parameters. A review by Pathan and Lokhande [77] outlines the advantages of SILAR over the CBD method. In the former, the deposition of a sufficiently thick film requires an extended period of time, which makes it crucial that it is operated with microprocessor or computer [18].

Das et al. [78] have prepared CoS-implanted graphene (G-CoS) film electrode using chemical vapor deposition and SILAR for DSSC. The prepared electrode was characterized in a dye sensitized solar cells (DSSCs). It reached better efficiency $\eta=3.42 \%$, while $J_{\mathrm{sc}}\left(\mathrm{mA} / \mathrm{cm}^{2}\right), V_{\mathrm{oc}}(\mathrm{V})$, and FF (\%) was $12.8,0.72$, and 36.4 , respectively.

Thin $\mathrm{ZnSe}$ layers were deposited on $\mathrm{ZnO}$ nanowires using SILAR method by Chung et al. [79] for DSSC application. The facilitation of electron transfer increased the $J_{\text {sc }}$, which was followed by improved efficiency.

3.5. Spray Pyrolysis Method. Spray pyrolysis is regarded as one of the most attractive and promising film preparation methods. It basically mirrors a film processing technique called thepyrosol technique, where a source solution is

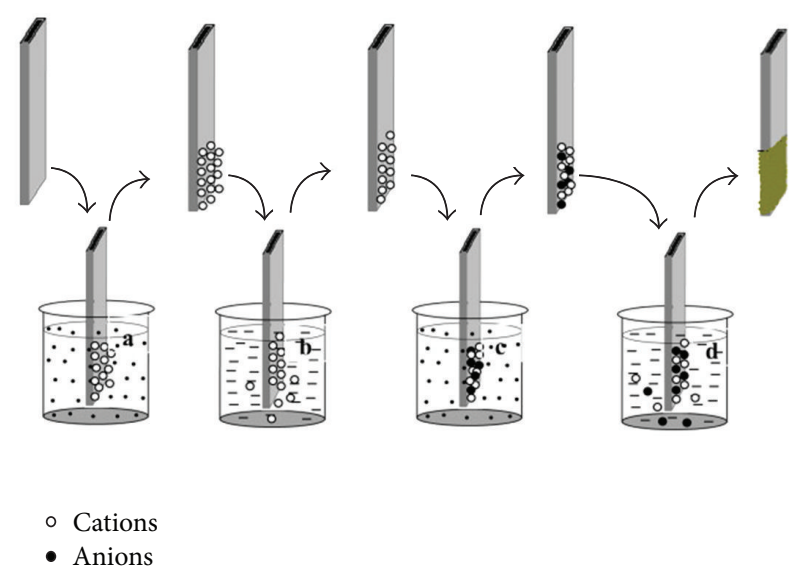

FIGURE 9: Schematic representation of SILAR method [71].

sprayed onto a heated substrate for it to be deposited in the form of a film. The mechanism of the process is as follows. The source solution is atomized, where small droplets splash and vaporize on a substrate, which results in the formation of a dry precipitate and thermal decomposition [80]. Figure 10 shows a schematic of the whole process.

3.5.1. Advantage and Disadvantages. Advantage and Disadvantages are as follows:

(i) does not require high quality targets or substrates;

(ii) being of low cost;

(iii) does not require a UHV system;

(iv) continuously produces the material;

(v) chemical reaction occurs within the created micron to submicron sized liquid droplets-a microcapsule reactor.

The technique is quite empirical, with a number of variables that can affect the final product such as solute concentration, atomization technique, temperature, temperature gradient, residence time in furnace, and carrier gases [80]. Table 5 represents research results using SPD method in preparation of DSSC. Figure 11 represents the comparison between spin coating and spray pyrolysis methods.

3.6. Sol-Gel Coating. The sol-gel process is also known as the chemical solution deposition, and it is classified as a wet chemical technique that is widely being applied in fields of materials science and ceramic engineering (Figure 12). It is mostly used for materials' synthesis (typically a metal oxide), initiated from a chemical solution that acts as the precursor for an integrated network (or gel) of discrete particles or network polymers. Some common precursors include metal alkoxides and chlorides, which are pegged to undergo multiple forms of hydrolysis and polycondensation reactions. Metal oxides are formed via the linkage of metal ions with oxo (M-O-M) or hydroxo (M-OH-M) bridges, which results in a metal-oxo or metal-hydroxo polymers forming in 


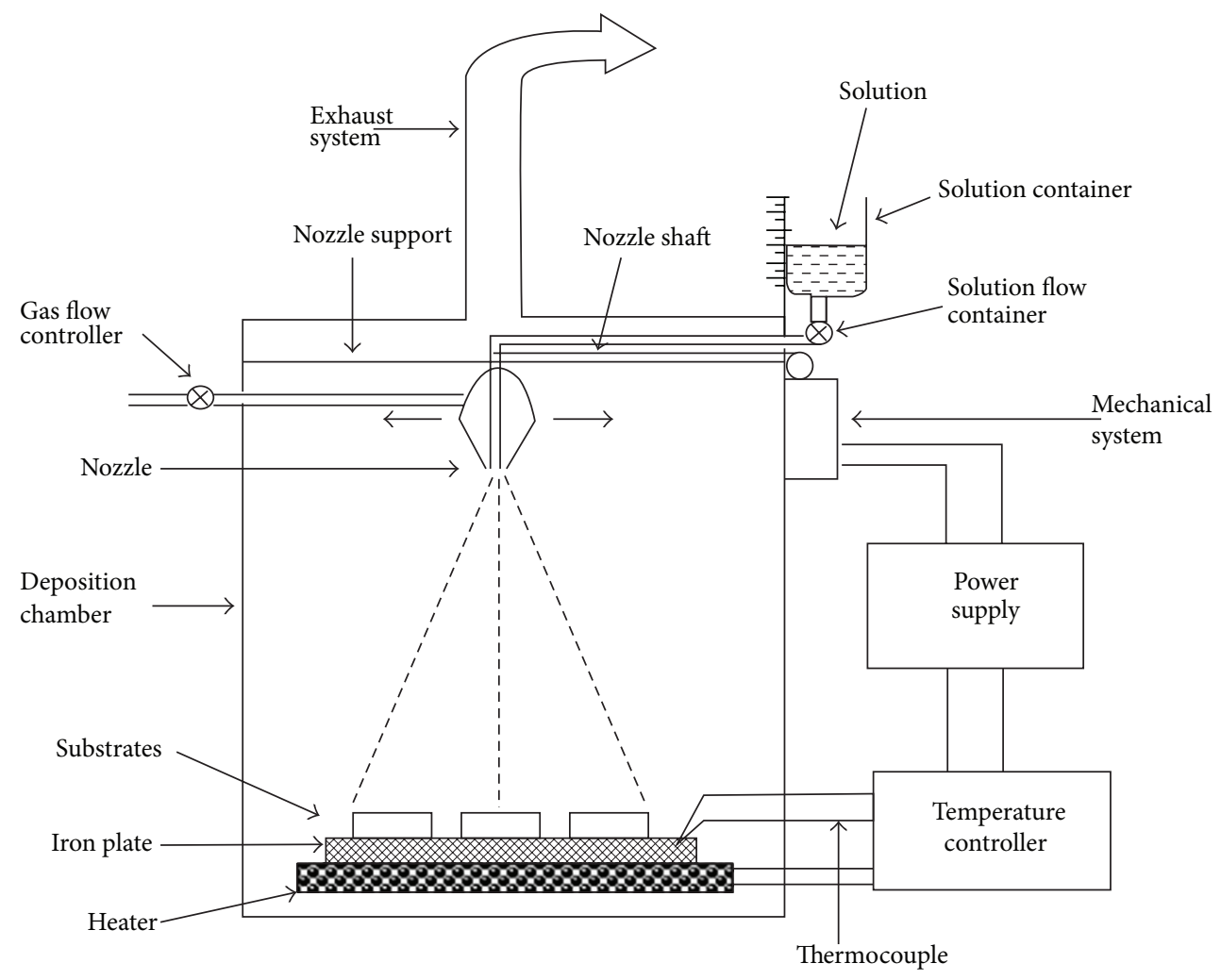

FIGURE 10: Schematic representation of spray pyrolysis method [18].

TABLE 5: SPD methods in preparation of DSSC.

\begin{tabular}{|c|c|c|c|}
\hline Materials & Method & Efficiency $(\eta) \%$ & Reference \\
\hline $\begin{array}{l}\text { Fluorine-doped tin oxide (FTO) } \\
\text { films coated on indium-tin oxide } \\
\text { (ITO) films }\end{array}$ & Spray pyrolysis deposition (SPD) & 3.7 & {$[191,192]$} \\
\hline $\begin{array}{l}\text { ITO-Pt semiconductor powder } \\
\text { containing nanoscale noble metal } \\
\text { particles }\end{array}$ & Spray pyrolysis & - & [193] \\
\hline $\mathrm{TiO}_{2}$ blocking layer & Spray pyrolysis & - & {$[194,195]$} \\
\hline Porous $\mathrm{TiO}_{2}$ films & Spray pyrolysis deposition & $3.2-5.1$ & {$[81,196]$} \\
\hline $\mathrm{TiO}_{2}$ nanocrystalline electrode & Atomized spray pyrolysis (ASP) & 8.2 & [197] \\
\hline $\mathrm{Nb}_{2} \mathrm{O}_{5}$ blocking layer & Spray pyrolysis & 3.35 & {$[198]$} \\
\hline $\begin{array}{l}\text { Boron-doped zinc oxide }\left(\mathrm{B}_{n} \mathrm{ZnO}\right) \\
\text { electrode }\end{array}$ & Spray pyrolysis deposition & 1.53 & [199] \\
\hline $\mathrm{ZnO}$ nanostructures & Spray pyrolysis & 4.7 & {$[200]$} \\
\hline
\end{tabular}

a solution. Thus, the sol gravitates towards a gel-like diphasic system of both liquid and solid, whose morphologies ranges from discrete particles to continuous polymer networks. The sol-gel technique is considered as a bridge for nanoparticles in the DSSC working electrodes such as $\mathrm{TiO}_{2}$ nanoparticles (P25 and P90) on polyethylene naphthalate (PEN) plastic sheet [82] and metal oxide semiconductor nanostructured such as zinc titanate (ZT), zinc oxide (ZO), and titanium dioxide (TD). The highest loading amount of dye and the best interaction between the semiconductor and dye are related to
$\mathrm{ZO}$, which has higher efficiency than the other cells. Due to its high electron conductivity, $\mathrm{ZnO}$ has the potential to enhance dye adsorption and highlight transmittance of a composite film [83]. Generally, the sol-gel process results in a highly pure product, homogenous, high adhesion, and strength and low temperature processing.

The Sol-gel method is one of the most used methods for materials preparation in DSSC. Certain recent research achievements using the sol-gel methods include $\mathrm{TiO}_{2}$ film and nanoparticles, $\mathrm{ZnO}, \mathrm{ZT}$ preparation for DSSC 


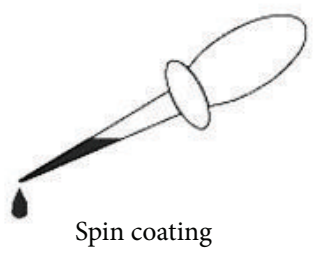

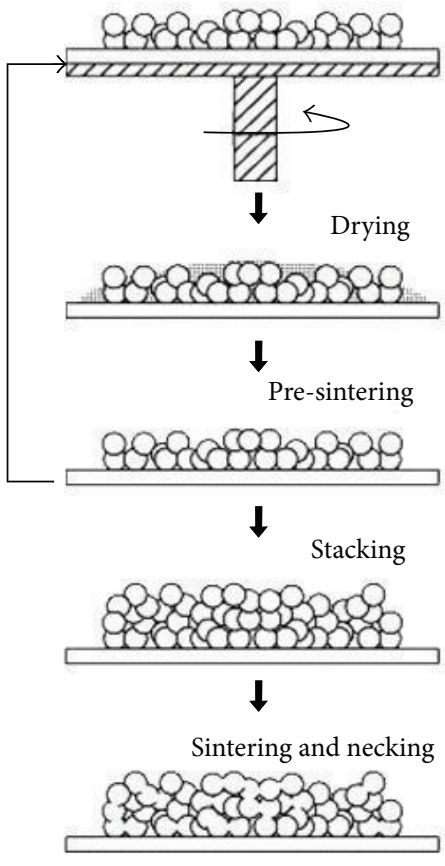

(a) Spin coating technique

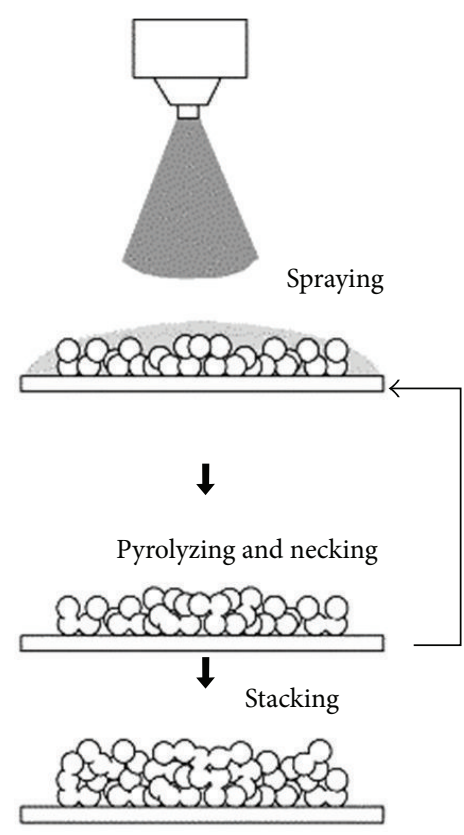

(b) SPD technique

FIGURE 11: Comparison between spin coating and SPD methods [81].

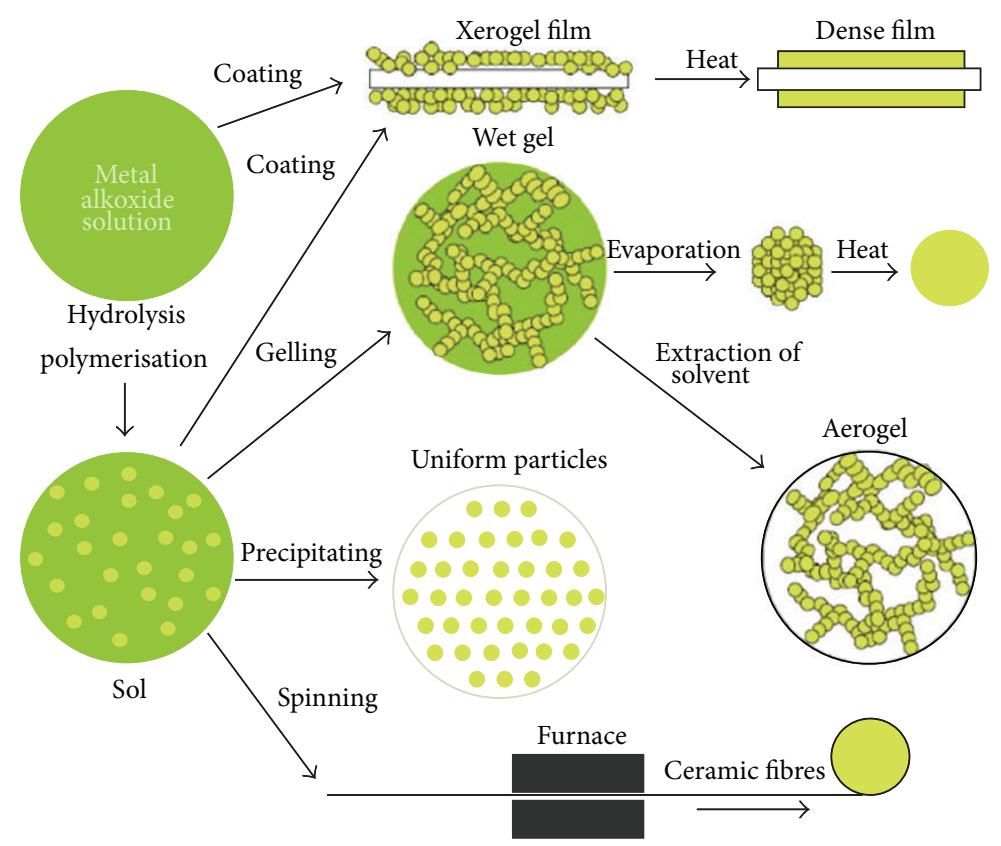

FIGURE 12: Schematic of sol-gel procedure and their products [84]. 
application $[82,83,85-90]$. Some researchers employ the solgel method in combination with physical deposition methods such as dip coating, spin coating, and electrospinning in order to synthesis $\mathrm{TiO}_{2}$, doped $\mathrm{TiO}_{2}$, and $\mathrm{TiO}_{2}$ composites [90-95].

Kwon et al. [96] used the sol-gel combustion method for the preparation of nanoporous F-doped tin dioxide films. The resulting DSSC managed to achieve an efficiency of $1.2 \%$.

3.7. Template Method. Among the many methods that can be used to fabricate ordered porous films (sputtering, chemical vapor deposition (CVD), spray pyrolysis and sol-gel process), the template method is the one that is mostly used, due to the fact that the pore's dimensions are determined by the size of the ordered template beads [97-100]. The result of this method is a material that is homogenous, pure, possessing novel morphology, structure, and properties.

However, it is commonly acknowledged that without being combined with another physical and chemical method, the end product of the template method is not up to par. The combination of template growth and sol-gel coating results in the fabrication of fine nanostructure of desired features [101-110]. Jiu et al. [102] reported template growth of porous $\mathrm{TiO}_{2}$ films with mixed polymers of Pluronic F127 and cetyltrimethylammonium bromide. Zukalová et al. [111] reported a similar structure with Pluronic P-123. Both works produce end products with very high surface areas but small pore diameters of $4-7 \mathrm{~nm}$ [102] and 6-8 nm [101], respectively.

Dionigi et al. presented a colloidal composite consisting of monodispersed polystyrene (PS), coated with a titanium oxide precursor named TALH that acts as a "structure director" for the fabrication of $\mathrm{TiO}_{2}$ films [112]. Meanwhile, Meng et al. assembled a highly ordered three-dimensional porous structure with commercial nanosized crystalline $\mathrm{TiO}_{2}$ particles via a cooperative method, where the fabrication of the template and the infiltration of its voids occur simultaneously [113]. Also, highly ordered $\mathrm{TiO}_{2}$ porous films were synthesized via a single-step assembly method, where the porous structures were prepared using polystyrene microspheres, with diameters [114]. Liu et al. prepared porous $\mathrm{ZnO}$ thin films that are assembled by multilayer PS templates, achievable by repeatedly employing the dip coating method [115]. Table 6 shows the result for DSSC prepared using template method.

3.8. Self-Assembly. Self-assembled nanosphere monolayers form the templates of nanosphere lithography and can usually be fabricated with techniques such as drop coating or spin coating [116-118] of polystyrene (PS) latex nanospheres. However, the difficulty in producing a low-defect and largearea nanosphere monolayer using this method is also noted [119].

Jhang et al. [119] have used spin-coating that in combination with the water transfer technique produced selfassembled layer for preparation of nanostructured Pt counter electrodes. This electrode achieved $V_{\mathrm{oc}}(\mathrm{V}), J_{\mathrm{sc}}\left(\mathrm{mA} / \mathrm{cm}^{2}\right), \mathrm{FF}$, and $\eta$ of $0.71,14.45,0.70$, and 7.18 , respectively. Template-free chemically induced self-transformation (CIST) method has employed by Yu et al. [120] for preparation of hollow anatase $\mathrm{TiO}_{2}$ spheres. The fabricated DSSC has been reached at $J_{\mathrm{sc}}$ $\left(\mathrm{mA} / \mathrm{cm}^{2}\right), V_{\text {oc }}(\mathrm{V}), \mathrm{FF}(\%)$, and $\eta(\%)$ of 14.7, 0.599, 0.547, and 4.82, respectively. Mesostructured titania thick films have been synthesized employing of evaporation-induced selfassembly using nonionic triblock copolymers as templating agents by Malfatti et al. [121].

3.9. Mechanical Methods. There are many mechanical techniques such as spraying, spinning, dipping and draining, flow coating, and roller coating, which are done for depositing coatings from a liquid media that subsequently reacted chemically to form the inorganic thin film product. These techniques are also classified in different ways compared to the physical deposition method, which requires a whole other discussion.

\section{Film Processing Techniques}

There are some techniques which can be used to enhance the materials' properties after their preparation, as well as their application for the preparation mix with some other preparation methods, namely, microwave or ultrasonic.

The deposited electrode materials on flexible substrate like polymers require an additional processing step to improve the necessary interparticle contact for their effective performance as an electrode material, as well as to improve the mechanical stability, namely, good film-substrate adhesion. Organic binders were used in making flexible DSSCs, but the absence of high temperature sintering of the metal oxide film on polymer substrates resulted in incomplete necking of the particles due to the presence of residual organics in the film [122]. UV/ozone and UV radiation treatments of the deposited metal oxide films were used by several groups as a method for eliminating adsorbed organic impurities on the surface of metal oxide films and improving the interparticle connection as another low temperature sintering method for flexible DSSCs [6, 123-127].

In order to realize the selective heating of organicinorganic composite films, microwave processing seems to be the most promising choice. Uchida et al. [128] used a $28 \mathrm{GHz}$ microwave irradiation process to produce a flexible DSSC. This particular technique is also applicable in the fabrication of PET-ITO film electrodes. A photoelectron energy conversion efficiency of $2.16 \%$ is realized for all-plastic cell fabricated by the $28 \mathrm{GHz}$ microwave irradiation, at $1.0 \mathrm{~kW}$ for 5 minutes.

Gan et al. [129] succeeding in fabricating a hybrid $\mathrm{ZnO}$ nanowire/ $\mathrm{TiO}_{2}$ nanoparticle photoanodes for DSSCs using an ultrasonic irradiation assisted dip-coating method. The gap-filling efficiency of $\mathrm{TiO}_{2}$ nanoparticles into the interstice voids of the $\mathrm{ZnO}$ nanowires was enhanced with the assistance of ultrasonic irradiation, which results in an increase of the total surface area, along with the light harvesting efficiency for the hybrid electrode. The effects of the ultrasonic treatment on the microstructure, the sensitization, and 
TABLE 6: Some research work on DSSC that used template method.

\begin{tabular}{|c|c|c|c|}
\hline Materials & Method & Efficiency $(\eta) \%$ & Reference \\
\hline $\begin{array}{l}\text { High-crystalline } \mathrm{TiO}_{2} \\
\text { nanoparticles as a thin-film }\end{array}$ & Mixed template of copolymer and surfactant & 8.24 & {$[102]$} \\
\hline Mesoporous titania nanocrystals & Sol-gel synthesis using surfactant as template & 4.08 & [201] \\
\hline $\begin{array}{l}\text { Organized mesoporous } \mathrm{TiO}_{2} \\
\text { films }\end{array}$ & $\begin{array}{l}\text { Supramoleculartemplating with an } \\
\text { amphiphilictriblock copolymer }\end{array}$ & - & {$[111]$} \\
\hline $\begin{array}{l}\text { Multilayered mesoporous } \mathrm{TiO}_{2} \\
\text { films }\end{array}$ & $\begin{array}{l}\text { Supramolecular templating and layer-by-layer } \\
\text { deposition }\end{array}$ & 5.12 & {$[202]$} \\
\hline $\begin{array}{l}\text { Nanocrystalline } \\
\text { mesoporoustitania }\end{array}$ & $\begin{array}{l}\text { Surfactant-assisted templating method and } \\
\text { doctor-blading technique }\end{array}$ & 8.06 & {$[203]$} \\
\hline Ordered nanoporous $\mathrm{TiO}_{2}$ & $\begin{array}{l}\text { Different silica templates and the squeeze } \\
\text { printing technique }\end{array}$ & 3.6 & {$[204]$} \\
\hline Hollow spherical $\mathrm{TiO}_{2}$ & Colloidal carbon spheres as templates & 5.64 & {$[205]$} \\
\hline Mesoporous anatase- $\mathrm{TiO}_{2}$ & Sol-gel using soft template and a hard template & 6.71 & {$[206]$} \\
\hline Anatase $\mathrm{TiO}_{2}$ hollow spheres & Chemical template method & 3.79 & {$[207]$} \\
\hline Ordered porous $\mathrm{TiO}_{2}$ thin films & Colloid crystal template & 1.269 & [208] \\
\hline Mesoporous $\mathrm{TiO}_{2}$ & $\begin{array}{l}\text { Sol-gel using water miscible ionic liquid } \\
\text { template }\end{array}$ & - & {$[209]$} \\
\hline Porous $\mathrm{TiO}_{2}$ films & Templated sol-gel method & - & {$[210]$} \\
\hline $\begin{array}{l}\text { Mesoporous nanocrystalline } \\
\mathrm{TiO}_{2} \text { films }\end{array}$ & $\begin{array}{l}\text { Hydrolysis-limited sol-gel process using block } \\
\text { copolymer as template }\end{array}$ & 0.31 & {$[211]$} \\
\hline $\begin{array}{l}\text { Center hollow } \mathrm{ZnO} \text { and } \mathrm{TiO}_{2} \\
\text { nanotubes arrays }\end{array}$ & $\begin{array}{l}\text { Electrodeposition, chemical etching, and } \\
\text { sol-gel process assisted by templates }\end{array}$ & 1.2 & {$[212]$} \\
\hline $\begin{array}{l}\text { Ferrocene-derivatized ordered } \\
\text { mesoporous carbon }\end{array}$ & Hard template method & 7.89 & {$[213]$} \\
\hline $\begin{array}{l}\text { Ordered mesoporous carbon } \\
\text { (OMC) }\end{array}$ & $\begin{array}{l}\text { Evaporation-induced triconstituent coassembly } \\
\text { method using soft-template method employing } \\
\text { triblock copolymer }\end{array}$ & 7.46 & {$[214]$} \\
\hline $\begin{array}{l}\text { MWCNT/mesoporous carbon } \\
\text { nanofibers composites }\end{array}$ & $\begin{array}{l}\text { Electrospinning, template etching, and thermal } \\
\text { process }\end{array}$ & 6.35 & {$[215]$} \\
\hline Nanoporous $\mathrm{NiO}$ films & $\begin{array}{l}\mathrm{NiCl}_{2} \text { in water/ethanol mixed solution, using } \\
\text { triblock copolymers as template }\end{array}$ & - & {$[216]$} \\
\hline Hollow silver microspheres & $\begin{array}{l}\text { Chemical deposition using sacrificial } \\
\text { templating method }\end{array}$ & - & {$[217]$} \\
\hline
\end{tabular}

the performance of hybrid $\mathrm{ZnO} \mathrm{NW} / \mathrm{TiO}_{2} \mathrm{NP}$ electrodes were thoroughly analyzed.

\section{Lessons Learned}

Taking into account the contents that are presented, it can be surmised that choosing an appropriate method is incumbent upon its parameters. For example, if the deposition rate is the primary parameter being considered, then the ALD and SILAR methods are ruled out, as they are detrimental in the context of deposition rates. If safety is of vital importance, then the use of CVD, ALD, and solvothermal/hydrothermal methods is not recommended. Furthermore, if one needs to synthesize materials that are unobtainable via solid-state reaction, the usage of solvothermal/hydrothermal method might be most suitable.

The preparation of thin films is highly reliant on the minute control of the materials at a molecular and atomic level, which encompasses surface modifications, deposition, and structuring. The preparation techniques and methods of thin film preparation have been significantly enhanced in the past decade due to better understanding of the physics and chemistry of thin films, along with their fundamental aspects, microstructural evolution, and their respective properties.

\section{Conclusion}

The selection of a specific deposition method needs variety of consideration and criteria such as thin film application, material characteristics, and process technology. It is found that there is no general guideline for choosing the best deposition method. However, different preparations and deposition technologies with materials' and substrates' type, specified application, cost, and requested efficiency allow the researchers to select a more appropriate technique for their research. Future work focuses more on the fabrication conditions and accounts for more parameters in order to compare the available chemical preparation methods in terms of their effect on DSSC efficiency, stability, durability cost, and optimization of the working conditions. 


\section{Conflict of Interests}

The authors declare that there is no conflict of interests regarding the publication of this paper.

\section{Acknowledgment}

The authors would like to thank the UKMDIP-2012-22 and DLP-2013-015 Research Funds for providing financial support to this study.

\section{References}

[1] L. Wang, X. Fang, and Z. Zhang, "Design methods for large scale dye-sensitized solar modules and the progress of stability research," Renewable and Sustainable Energy Reviews, vol. 14, no. 9, pp. 3178-3184, 2010.

[2] Y.-D. Zhang, X.-M. Huang, D.-M. Li, Y.-H. Luo, and Q.-B. Meng, "How to improve the performance of dye-sensitized solar cell modules by light collection," Solar Energy Materials and Solar Cells, vol. 98, pp. 417-423, 2012.

[3] Y.-D. Zhang, X.-M. Huang, Y.-Y. Yang et al., "How to improve the performance of dye-sensitized solar modules by 'back leads"' Solar Energy Materials and Solar Cells, vol. 102, pp. 109113, 2012.

[4] Q. Zhang and G. Cao, "Nanostructured photoelectrodes for dye-sensitized solar cells," Nano Today, vol. 6, no. 1, pp. 91-109, 2011.

[5] J. Gong, J. Liang, and K. Sumathy, "Review on dye-sensitized solar cells (DSSCs): fundamental concepts and novel materials," Renewable and Sustainable Energy Reviews, vol. 16, no. 8, pp. 5848-5860, 2012.

[6] H. C. Weerasinghe, F. Huang, and Y.-B. Cheng, "Fabrication of flexible dye sensitized solar cells on plastic substrates," Nano Energy, vol. 2, no. 2, pp. 174-189, 2013.

[7] K. L. Choy, "Chemical vapour deposition of coatings," Progress in Materials Science, vol. 48, no. 2, pp. 57-170, 2003.

[8] K. Seshan, Handbook of Thin-Film Deposition Processes and Techniques Principles, Methods, Equipment and Applications, Noyes Publications/William Andrew Publishing, Norwich, NY, USA, 2nd edition, 2002.

[9] J. L. Zilko, "Metal organic chemical vapor deposition: technology and equipment," in Handbook of Thin Film Deposition Processes and Techniques: Principles, Methods, Equipment and Applications, K. Seshan, Ed., 2002.

[10] H. Kim, H.-B.-R. Lee, and W. J. Maeng, "Applications of atomic layer deposition to nanofabrication and emerging nanodevices," Thin Solid Films, vol. 517, no. 8, pp. 2563-2580, 2009.

[11] H. Kim, Nanomaterials \& Nanopatterning, Yonsei University.

[12] S. M. George, "Atomic layer deposition: an overview," Chemical Reviews, vol. 110, no. 1, pp. 111-131, 2010.

[13] M. Ritala and M. Leskelä, "Atomic layer deposition," in Handbook of Thin Films, H. S. Nalwa, Ed., pp. 103-159, Academic Press, Burlington, Mass, USA, 2002.

[14] C. Goh, Growth of $\mathrm{SiO}_{2}$, Microelectronics Process and Device Simulation Center, 2013.

[15] S. Choopun, A. Tubtimtae, T. Santhaveesuk, S. Nilphai, E. Wongrat, and N. Hongsith, "Zinc oxide nanostructures for applications as ethanol sensors and dye-sensitized solar cells," Applied Surface Science, vol. 256, no. 4, pp. 998-1002, 2009.
[16] Y.-T. Kim, J. Park, and J. Choi, "Sputter-deposited ZnO thin films consisting of nano-networks for binder-free dyesensitized solar cells," Current Applied Physics, vol. 13, no. 2, pp. 381-385, 2013.

[17] F. Hossein-Babaei and S. Rahbarpour, "Titanium and silver contacts on thermally oxidized titanium chip: electrical and gas sensing properties," Solid-State Electronics, vol. 56, no. 1, pp. 185190, 2011.

[18] C. D. Lokhande, A. M. More, and J. L. Gunjakar, "Microstructure dependent performance of chemically deposited nanocrystalline metal oxide thin films," Journal of Alloys and Compounds, vol. 486, no. 1-2, pp. 570-580, 2009.

[19] M. Paunovic and M. Schlesinger, Fundamentals of Electrochemical Deposition, Wiley-Interscience, Hoboken, NJ, USA, 2006.

[20] X.-J. Wu, F. Zhu, C. Mu et al., "Electrochemical synthesis and applications of oriented and hierarchically quasi-1D semiconducting nanostructures," Coordination Chemistry Reviews, vol. 254, no. 9-10, pp. 1135-1150, 2010.

[21] A. M. Fernandez, M. E. Calixto, P. J. Sebastian, S. A. Gamboa, A. M. Hermann, and R. N. Noufi, "Electrodeposited and selenized (CuInSe2) (CIS) thin films for photovoltaic applications," Solar Energy Materials and Solar Cells, vol. 52, no. 3-4, pp. 423-431, 1998.

[22] G. Zou, H. Li, Y. Zhang, K. Xiong, and Y. Qian, "Solvother$\mathrm{mal} /$ hydrothermal route to semiconductor nanowires," Nanotechnology, vol. 17, no. 11, pp. S313-S320, 2006.

[23] K. Zajączkowski, Solvothermal Synthesis, 2011.

[24] A. Rabenau, "Role of hydrothermal synthesis in preparative chemistry," Angewandte Chemie - International Edition, vol. 24, no. 12, pp. 1026-1040, 1985.

[25] K. Eda, Hydrothermal Synthesis, Kobe University, 2006.

[26] S. Sōmiya and R. Roy, "Hydrothermal synthesis of fine oxide powders," Bulletin of Materials Science, vol. 23, no. 6, pp. 453460, 2000.

[27] Y. G. Guo, Hydrothermal/Solvothermal Synthesis of Nanomaterials, 2010

[28] I. Tacchini, A. Ansón-Casaos, Y. Yu, M. T. Martínez, and M. Lira-Cantu, "Hydrothermal synthesis of $1 \mathrm{D} \mathrm{TiO}_{2}$ nanostructures for dye sensitized solar cells," Materials Science and Engineering B, vol. 177, no. 1, pp. 19-26, 2012.

[29] Y. Zhao, X. Gu, and Y. Qiang, "Influence of growth time and annealing on rutile $\mathrm{TiO}_{2}$ single-crystal nanorod arrays synthesized by hydrothermal method in dye-sensitized solar cells," Thin Solid Films, vol. 520, no. 7, pp. 2814-2818, 2012.

[30] J.-K. Oh, J.-K. Lee, B. Han, S.-J. Kim, and K.-W. Park, "TiO, rutile nanowire electrodes for dye-sensitized solar cells," Materials Letters, vol. 68, pp. 4-7, 2012.

[31] J. Jung, J. Myoung, and S. Lim, "Effects of $\mathrm{ZnO}$ nanowire synthesis parameters on the photovoltaic performance of dyesensitized solar cells," Thin Solid Films, vol. 520, no. 17, pp. 57795789, 2012.

[32] Y. Kim, J. H. Jeong, and M. Kang, "Rapid synthesis of bis $\left(2,2^{\prime}\right.$-bipyridine) nitratocopper(II) nitrate using a hydrothermal method and its application to dye-sensitized solar cells," Inorganica Chimica Acta, vol. 365, no. 1, pp. 400-407, 2011.

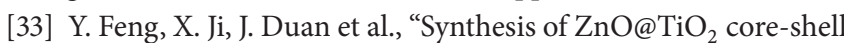
long nanowire arrays and their application on dye-sensitized solar cells," Journal of Solid State Chemistry, vol. 190, pp. 303308, 2012.

[34] C. Lao, Y. Chuai, L. Su et al., "Mix-solvent-thermal method for the synthesis of anatase nanocrystalline titanium dioxide used 
in dye-sensitized solar cell," Solar Energy Materials and Solar Cells, vol. 85, no. 3, pp. 457-465, 2005.

[35] M. S. Akhtar, M. A. Khan, M. S. Jeon, and O. B. Yang, "Controlled synthesis of various $\mathrm{ZnO}$ nanostructured materials by capping agents-assisted hydrothermal method for dyesensitized solar cells," Electrochimica Acta, vol. 53, no. 27, pp. 7869-7874, 2008.

[36] S. Ito, T. N. Murakami, P. Comte et al., "Fabrication of thin film dye sensitized solar cells with solar to electric power conversion efficiency over 10\%," Thin Solid Films, vol. 516, no. 14, pp. 46134619, 2008.

[37] C.-H. Huang, Y.-T. Yang, and R.-A. Doong, "Microwaveassisted hydrothermal synthesis of mesoporous anatase $\mathrm{TiO}_{2}$ via sol-gel process for dye-sensitized solar cells," Microporous and Mesoporous Materials, vol. 142, no. 2-3, pp. 473-480, 2011.

[38] W. H. Sutton, "Microwave processing of ceramic materials," The American Ceramic Society Bulletin, vol. 68, no. 2, pp. 376-386, 1989.

[39] D. M. P. Mingos and D. R. Baghurst, "Applications of microwave dielectirc heating effects to synthetic problems in chemistry," Chemical Society Reviews, vol. 20, no. 1, pp. 1-47, 1991.

[40] S. G. Deng and Y. S. Lin, "Microwave synthesis of mesoporous and microporous alumina powders," Journal of Materials Science Letters, vol. 16, no. 15, pp. 1291-1294, 1997.

[41] R. Roy, D. Agrawal, J. Cheng, and S. Gedevanishvili, "Full sintering of powdered-metal bodies in a microwave field," Nature, vol. 399, pp. 668-670, 1999.

[42] K. J. Rao, P. A. Ramakrishnan, and R. Gadagkar, "Microwave preparation of oxide bronzes," Journal of Solid State Chemistry, vol. 148, no. 1, pp. 100-107, 1999.

[43] C. Feldmann and H.-O. Jungk, "Polyol-mediated preparation of nanoscale oxide particles," Angewandte Chemie-International Edition, vol. 40, no. 2, pp. 359-362, 2001.

[44] T. Yamamoto, Y. Wada, H. Yin, T. Sakata, H. Mori, and S. Yanagida, "Microwave-driven polyol method for preparation of $\mathrm{TiO}_{2}$ nanocrystallites," Chemistry Letters, no. 10, pp. 964-965, 2002.

[45] S. Uchida, M. Tomiha, N. Masaki, A. Miyazawa, and H. Takizawa, "Preparation of $\mathrm{TiO}_{2}$ nanocrystalline electrode for dye-sensitized solar cells by $28 \mathrm{GHz}$ microwave irradiation," Solar Energy Materials and Solar Cells, vol. 81, no. 1, pp. 135-139, 2004.

[46] X. Hu, G. Li, and J. C. Yu, "Design, fabrication, and modification of nanostructured semiconductor materials for environmental and energy applications," Langmuir, vol. 26, no. 5, pp. 3031$3039,2010$.

[47] G. J. Wilson, A. S. Matijasevich, D. R. G. Mitchell, J. C. Schulz, and G. D. Will, "Modification of $\mathrm{TiO}_{2}$ for enhanced surface properties: finite ostwald ripening by a microwave hydrothermal process," Langmuir, vol. 22, no. 5, pp. 2016-2027, 2006.

[48] P. Zhang, S. Yin, and T. Sato, "Synthesis of high-activity $\mathrm{TiO}_{2}$ photocatalyst via environmentally friendly and novel microwave assisted hydrothermal process," Applied Catalysis $B$, vol. 89, no. 1-2, pp. 118-122, 2009.

[49] J. N. Hart, R. Cervini, Y. B. Cheng, G. P. Simon, and L. Spiccia, "Formation of anatase $\mathrm{TiO}_{2}$ by microwave processing," Solar Energy Materials and Solar Cells, vol. 84, no. 1-4, pp. 135-143, 2004.

[50] I. Zumeta, J. A. Ayllón, B. González, X. Domenech, and E. Vigil, " $\mathrm{TiO}_{2}$ films obtained by microwave-activated chemical-bath deposition used to improve $\mathrm{TiO}_{2}$-conducting glass contact," Solar Energy Materials and Solar Cells, vol. 93, no. 10, pp. 17281732, 2009.

[51] S. Ribbens, V. Meynen, G. V. Tendeloo et al., "Development of photocatalytic efficient Ti-based nanotubes and nanoribbons by conventional and microwave assisted synthesis strategies," Microporous and Mesoporous Materials, vol. 114, no. 1-3, pp. 401-409, 2008.

[52] Y. Li, H. Li, T. Li, G. Li, and R. Cao, "Facile synthesis of mesoporous titanium dioxide nanocomposites with controllable phase compositions by microwave-assisted esterification," Microporous and Mesoporous Materials, vol. 117, no. 1-2, pp. 444449, 2009.

[53] P. Periyat, N. Leyland, D. E. McCormack, J. Colreavy, D. Corr, and S. C. Pillai, "Rapid microwave synthesis of mesoporous $\mathrm{TiO}_{2}$ for electrochromic displays," Journal of Materials Chemistry, vol. 20, no. 18, pp. 3650-3655, 2010.

[54] A. C. Cakir and S. Erten-Ela, "Comparison between synthesis techniques to obtain $\mathrm{ZnO}$ nanorods and its effect on dye sensitized solar cells," Advanced Powder Technology, vol. 23, no. 5, pp. 655-660, 2012.

[55] K. D. Bhatte, P. Tambade, S. Fujita, M. Arai, and B. M. Bhanage, "Microwave-assisted additive free synthesis of nanocrystalline zinc oxide," Powder Technology, vol. 203, no. 2, pp. 415-418, 2010.

[56] S. Brahma and S. A. Shivashankar, "Microwave irradiationassisted method for the deposition of adherent oxide films on semiconducting and dielectric substrates," Thin Solid Films, vol. 518, no. 21, pp. 5905-5911, 2010.

[57] N. Mir, M. Salavati-Niasari, and F. Davar, "Preparation of ZnO nanoflowers and $\mathrm{Zn}$ glycerolate nanoplates using inorganic precursors via a convenient rout and application in dye sensitized solar cells," Chemical Engineering Journal, vol. 181-182, pp. 779789, 2012

[58] K. S. Suslick, S.-B. Choe, A. A. Cichowlas, and M. W. Grinstaff, "Sonochemical synthesis of amorphous iron," Nature, vol. 353, no. 6343, pp. 414-416, 1991.

[59] K. S. Suslick, Ultrasound: Its Chemical, Physical, and Biological Effects, Wiley-VCH, New York, NY, USA, 1988.

[60] K. S. Suslick and G. J. Price, "Applications of ultrasound to materials chemistry," Annual Review of Materials Science, vol. 29, pp. 295-326, 1999.

[61] Y.-Q. Wang, S.-G. Chen, X.-H. Tang et al., "Mesoporous titanium dioxide: sonochemical synthesis and application in dye-sensitized solar cells," Journal of Materials Chemistry, vol. 11, no. 2, pp. 521-526, 2001.

[62] A. Tubtimtae and M. W. Lee, " $\mathrm{ZnO}$ nanorods on undoped and indium-doped $\mathrm{ZnO}$ thin films as a TCO layer on nonconductive glass for dye-sensitized solar cells," Superlattices and Microstructures, vol. 52, no. 5, pp. 987-996, 2012.

[63] M. Thambidurai, N. Muthukumarasamy, D. Velauthapillai, and C. Lee, "Synthesis of garland like $\mathrm{ZnO}$ nanorods and their application in dye sensitized solar cells," Materials Letters, vol. 92, pp. 104-107, 2013.

[64] P. K. Baviskar, J. B. Zhang, V. Gupta, S. Chand, and B. R. Sankapal, "Nanobeads of zinc oxide with rhodamine B dye as a sensitizer for dye sensitized solar cell application," Journal of Alloys and Compounds, vol. 510, no. 1, pp. 33-37, 2011.

[65] Y. Wang, X. Cui, Y. Zhang, X. Gao, and Y. Sun, "Preparation of cauliflower-like $\mathrm{ZnO}$ films by chemical bath deposition: photovoltaic performance and equivalent circuit of dye-sensitized solar cells," Journal of Materials Science and Technology, vol. 29, no. 2, pp. 123-127, 2013. 
[66] L. Luo, W. Tao, X. Hu et al., "Mesoporous F-doped ZnO prism arrays with significantly enhanced photovoltaic performance for dye-sensitized solar cells," Journal of Power Sources, vol. 196, no. 23, pp. 10518-10525, 2011.

[67] Y.-M. Lee and H.-W. Yang, "Optimization of processing parameters on the controlled growth of $\mathrm{ZnO}$ nanorod arrays for the performance improvement of solid-state dye-sensitized solar cells," Journal of Solid State Chemistry, vol. 184, no. 3, pp. 615623, 2011.

[68] N. Karst, G. Rey, B. Doisneau et al., "Fabrication and characterization of a composite $\mathrm{ZnO}$ semiconductor as electron transporting layer in dye-sensitized solar cells," Materials Science and Engineering B, vol. 176, no. 8, pp. 653-659, 2011.

[69] K. Yuan, X. Yin, J. Li, J. Wu, Y. Wang, and F. Huang, "Preparation and DSC application of the size-tuned $\mathrm{ZnO}$ nanoarrays," Journal of Alloys and Compounds, vol. 489, no. 2, pp. 694-699, 2010.

[70] E. Vigil, B. González, I. Zumeta et al., "The role of conductingoxide-substrate type and morphology in $\mathrm{TiO}_{2}$ films grown by microwave chemical bath deposition (MW-CBD) and their photovoltaic characteristics," Journal of Crystal Growth, vol. 262, no. 1-4, pp. 366-374, 2004.

[71] S. M. Pawar, B. S. Pawar, J. H. Kim, O.-S. Joo, and C. D. Lokhande, "Recent status of chemical bath deposited metal chalcogenide and metal oxide thin films," Current Applied Physics, vol. 11, no. 2, pp. 117-161, 2011.

[72] C.-M. Chen, C.-H. Chen, and T.-C. Wei, "Chemical deposition of platinum on metallic sheets as counterelectrodes for dyesensitized solar cells," Electrochimica Acta, vol. 55, no. 5, pp. 1687-1695, 2010.

[73] J.-L. Lan, Y.-Y. Wang, C.-C. Wan et al., "The simple and easy way to manufacture counter electrode for dye-sensitized solar cells," Current Applied Physics, vol. 10, no. 2, pp. S168-S171, 2010.

[74] Y. Li, H. Zhang, B. Guo, and M. Wei, "Enhanced efficiency dye-sensitized $\mathrm{SrSnO}_{3}$ solar cells prepared using chemical bath deposition," Electrochimica Acta, vol. 70, pp. 313-317, 2012.

[75] M. Ristov, G. Sinadinovski, and I. Grozdanov, "Chemical deposition of $\mathrm{Cu}_{2} \mathrm{O}$ thin films," Thin Solid Films, vol. 123, no. 1, pp. 63-67, 1985.

[76] Y. F. Nicolau, "Solution deposition of thin solid compound films by a successive ionic-layer adsorption and reaction process," Applied Surface Science, vol. 22-23, no. 2, pp. 1061-1074, 1985.

[77] H. M. Pathan and C. D. Lokhande, "Deposition of metal chalcogenide thin films by successive ionic layer adsorption and reaction (SILAR) method," Bulletin of Materials Science, vol. 27, no. 2, pp. 85-111, 2004.

[78] S. Das, P. Sudhagar, S. Nagarajan et al., "Synthesis of grapheneCoS electro-catalytic electrodes for dye sensitized solar cells," Carbon, vol. 50, no. 13, pp. 4815-4821, 2012.

[79] J. Chung, J. Myoung, J. Oh, and S. Lim, "Successive ionic layer adsorption and reaction of $\mathrm{ZnSe}$ shells for $\mathrm{ZnO}$ nanowire-based dye-sensitized solar cells," Journal of Physics and Chemistry of Solids, vol. 73, no. 4, pp. 535-539, 2012.

[80] P. S. Patil, "Versatility of chemical spray pyrolysis technique," Materials Chemistry and Physics, vol. 59, no. 3, pp. 185-198, 1999.

[81] M. Okuya, K. Nakade, D. Osa, T. Nakano, G. R. A. Kumara, and S. Kaneko, "Fabrication of dye-sensitized solar cells by spray pyrolysis deposition (SPD) technique," Journal of Photochemistry and Photobiology A, vol. 164, no. 1-3, pp. 167-172, 2004.

[82] W.-H. Yen, C. C. Hsieh, H. W. Wang, C. Y. Hung, and M. C. Tsui, "Flexible $\mathrm{TiO}_{2}$ working electrode for dye-sensitized solar cells," Journal of the Chinese Chemical Society, vol. 57, no. 5, pp. 1162-1166, 2010.

[83] M. H. Habibi, M. Mikhak, M. Zendehdel, and M. Habibi, "Influence of nanostructured zinc titanate, zinc oxide or titanium dioxide thin film coated on fluorine doped tin oxide as working electrodes for dye-sensitized solar cell," International Journal of Electrochemical Science, vol. 7, pp. 6787-6798, 2012.

[84] A. Cannavale, F. Fiorito, M. Manca, G. Tortorici, R. Cingolani, and G. Gigli, "Multifunctional bioinspired sol-gel coatings for architectural glasses," Building and Environment, vol. 45, no. 5, pp. 1233-1243, 2010.

[85] J.-Y. Bae, D. Lim, H.-G. Yun, M. Kim, J. Jin, and B.-S. Bae, "A quasi-solid-state dye-sensitized solar cell based on sol-gel derived in situ gelation of a siloxane hybrid electrolyte," RSC Advances, vol. 2, no. 13, pp. 5524-5527, 2012.

[86] H. J. Jung, "Characterization of $\mathrm{TiO}_{2}$ nanocrystalline films for high performance dye-sensitized solar cells," Transactions on Electrical and Electronic Materials, vol. 12, no. 3, pp. 123-126, 2011.

[87] M. Boucharef, C. Di Bin, M. S. Boumaza et al., "Solid-state dyesensitized solar cells based on $\mathrm{ZnO}$ nanocrystals," Nanotechnology, vol. 21, no. 20, Article ID 205203, 2010.

[88] S. Rani, P. Suri, P. K. Shishodia, and R. M. Mehra, "Synthesis of nanocrystalline $\mathrm{ZnO}$ powder via sol-gel route for dye-sensitized solar cells," Solar Energy Materials and Solar Cells, vol. 92, no. 12, pp. 1639-1645, 2008.

[89] A. O. T. Patrocínio, E. B. Paniago, R. M. Paniago, and N. Y. M. Iha, "XPS characterization of sensitized $\mathrm{n}-\mathrm{TiO}_{2}$ thin films for dye-sensitized solar cell applications," Applied Surface Science, vol. 254, no. 6, pp. 1874-1879, 2008.

[90] J. N. Hart, D. Menzies, Y.-B. Cheng, G. P. Simon, and L. Spiccia, " $\mathrm{TiO}_{2}$ sol-gel blocking layers for dye-sensitized solar cells," Comptes Rendus Chimie, vol. 9, no. 5-6, pp. 622-626, 2006.

[91] W. H. Jung, N.-S. Kwak, T. S. Hwang, and K. B. Yi, "Preparation of highly porous $\mathrm{TiO}_{2}$ nanofibers for dye-sensitized solar cells (DSSCs) by electro-spinning," Applied Surface Science, vol. 261, pp. 343-352, 2012.

[92] Y. Chen, E. Stathatos, and D. D. Dionysiou, "Sol-gel modified $\mathrm{TiO}_{2}$ powder films for high performance dye-sensitized solar cells," Journal of Photochemistry and Photobiology A, vol. 203, no. 2-3, pp. 192-198, 2009.

[93] Y.-M. Lee, C.-H. Hsu, and H.-W. Chen, "Structural, optical, and electrical properties of p-type $\mathrm{NiO}$ films and composite $\mathrm{TiO}_{2} / \mathrm{NiO}$ electrodes for solid-state dye-sensitized solar cells," Applied Surface Science, vol. 255, no. 8, pp. 4658-4663, 2009.

[94] Y. Zhang, Y. Shen, F. Gu, M. Wu, Y. Xie, and J. Zhang, "Influence of $\mathrm{Fe}$ ions in characteristics and optical properties of mesoporous titanium oxide thin films," Applied Surface Science, vol. 256, no. 1, pp. 85-89, 2009.

[95] J. Sabataityte, I. Oja, F. Lenzmann, O. Volobujeva, and M. Krunks, "Characterization of nanoporous $\mathrm{TiO}_{2}$ films prepared by sol-gel method," Comptes Rendus Chimie, vol. 9, no. 5-6, pp. 708-712, 2006.

[96] H.-M. Kwon, D.-W. Han, D.-J. Kwak, and Y.-M. Sung, "Preparation of nanoporous F-doped tin dioxide films for TCO-less dye-sensitized solar cells application," Current Applied Physics, vol. 10, no. 2, pp. S172-S175, 2010.

[97] F. Bosc, P. Lacroix-Desmazes, and A. Ayral, " $\mathrm{TiO}_{2}$ anatasebased membranes with hierarchical porosity and photocatalytic properties," Journal of Colloid and Interface Science, vol. 304, no. 2, pp. 545-548, 2006. 
[98] O. D. Velev, P. M. Tessier, A. M. Lenhoff, and E. W. Kaler, "A class of porous metallic nanostructures," Nature, vol. 401, no. 6753, p. $548,1999$.

[99] L. J. Fu, T. Zhang, Q. Cao, H. P. Zhang, and Y. P. Wu, "Preparation and characterization of three-dimensionally ordered mesoporous titania microparticles as anode material for lithium ion battery," Electrochemistry Communications, vol. 9, no. 8, pp. 2140-2144, 2007.

[100] Y. Lan, X. Gao, H. Zhu et al., "Titanate nanotubes and nanorods prepared from rutile powder," Advanced Functional Materials, vol. 15, no. 8, pp. 1310-1318, 2005.

[101] M. Zukalovà, A. Zukal, L. Kavan, M. K. Nazeeruddin, P. Liska, and M. Grätzel, "Organized mesoporous $\mathrm{TiO}_{2}$ films exhibiting greatly enhanced performance in dye-sensitized solar cells," Nano Letters, vol. 5, no. 9, pp. 1789-1792, 2005.

[102] J. Jiu, F. Wang, M. Sakamoto, J. Takao, and M. Adachi, "Performance of dye-sensitized solar cell based on nanocrystals $\mathrm{TiO}_{2}$ film prepared with mixed template method," Solar Energy Materials and Solar Cells, vol. 87, no. 1-4, pp. 77-86, 2005.

[103] J. E. G. J. Wijnhoven and W. L. Vos, "Preparation of photonic crystals made of air spheres in titania," Science, vol. 281, no. 5378, pp. 802-804, 1998.

[104] P. Jiang, J. Cizeron, J. F. Bertone, and V. L. Colvin, "Preparation of macroporous metal films from colloidal crystals," Journal of the American Chemical Society, vol. 121, no. 34, pp. 7957-7958, 1999.

[105] P. Ni, B. Cheng, and D. Zhang, "Inverse opal with an ultraviolet photonic gap," Applied Physics Letters, vol. 80, no. 11, pp. 18791881, 2002.

[106] B. T. Holland, C. F. Blanford, and A. Stein, "Synthesis of macroporous minerals with highly ordered three-dimensional arrays of spheroidal voids," Science, vol. 281, no. 5376, pp. 538540, 1998.

[107] M. E. Abdelsalam, P. N. Bartlett, J. J. Baumberg, and S. Coyle, "Preparation of arrays of isolated spherical cavities by self-assembly of polystyrene spheres on self-assembled prepatterned macroporous films," Advanced Materials, vol. 16, no. 1, pp. 90-93, 2004.

[108] Z. Zhong, Y. Yin, B. Gates, and Y. Xia, "Preparation of mesoscale hollow spheres of $\mathrm{TiO}_{2}$ and $\mathrm{SnO}_{2}$ by templating against crystalline arrays of polystyrene beads," Advanced Materials, vol. 12, no. 3, pp. 206-209, 2000.

[109] A. Richel, N. P. Johnson, and D. W. McComb, "Observation of Bragg reflection in photonic crystals synthesized from air spheres in a titania matrix," Applied Physics Letters, vol. 76, no. 14, pp. 1816-1818, 2000.

[110] Z. Zhou and X. S. Zhao, "Opal and inverse opal fabricated with a flow-controlled vertical deposition method," Langmuir, vol. 21, no. 10, pp. 4717-4723, 2005.

[111] M. Zukalová, J. Procházka, A. Zukal, J. H. Yum, and L. Kavan, "Structural parameters controlling the performance of organized mesoporous $\mathrm{TiO}_{2}$ films in dye sensitized solar cells," Inorganica Chimica Acta, vol. 361, no. 3, pp. 656-662, 2008.

[112] C. Dionigi, P. Greco, G. Ruani, M. Cavallini, F. Borgatti, and F. Biscarini, "3D hierarchical porous $\mathrm{TiO}_{2}$ films from colloidal composite fluidic deposition," Chemistry of Materials, vol. 20, no. 22, pp. 7130-7135, 2008.

[113] Q. B. Meng, C. H. Fu, Y. Einaga, Z. Z. Gu, A. Fujishima, and O. Sato, "Assembly of highly ordered three-dimensional porous structure with nanocrystalline $\mathrm{TiO}_{2}$ semiconductors," Chemistry of Materials, vol. 14, no. 1, pp. 83-88, 2002.
[114] R. A. Doong, S. M. Chang, Y. C. Hung, and I. L. Kao, "Preparation of highly ordered titanium dioxide porous films: characterization and photocatalytic activity," Separation and Purification Technology, vol. 58, no. 1, pp. 192-199, 2007.

[115] Z. H. Liu, X. S. Cheng, H. Q. Yang, X. L. Chai, and X. X. Liu, "Deformation and energy-absorption characteristics of thinwall straight beam under central collision," Journal of Jilin University (Engineering and Technology Edition), vol. 36, no. 1, pp. 25-30, 2006.

[116] J. C. Hulteen and R. P. van Duyne, "Nanosphere lithography: a materials general fabrication process for periodic particle array surfaces," Journal of Vacuum Science and Technology A, vol. 13, no. 3, pp. 1553-1558, 1995.

[117] R. Micheletto, H. Fukuda, and M. Ohtsu, "A simple method for the production of a two-dimensional, ordered array of small latex particles," Langmuir, vol. 11, no. 9, pp. 3333-3336, 1995.

[118] T. Ogi, L. B. Modesto-Lopez, F. Iskandar, and K. Okuyama, "Fabrication of a large area monolayer of silica particles on a sapphire substrate by a spin coating method," Colloids and Surfaces A, vol. 297, no. 1-3, pp. 71-78, 2007.

[119] Y.-H. Jhang, Y.-T. Tsai, C.-H. Tsai et al., "Nanostructured platinum counter electrodes by self-assembled nanospheres for dye-sensitized solar cells," Organic Electronics, vol. 13, no. 10, pp. 1865-1872, 2012.

[120] J. Yu, J. Fan, and L. Zhao, "Dye-sensitized solar cells based on hollow anatase $\mathrm{TiO}_{2}$ spheres prepared by self-transformation method," Electrochimica Acta, vol. 55, no. 3, pp. 597-602, 2010.

[121] L. Malfatti, P. Falcaro, H. Amenitsch et al., "Mesostructured selfassembled titania films for photovoltaic applications," Microporous and Mesoporous Materials, vol. 88, no. 1-3, pp. 304-311, 2006.

[122] C. Cheng, J. Wu, Y. Xiao et al., "Polyvinyl pyrrolidone aided preparation of $\mathrm{TiO}_{2}$ films used in flexible dye-sensitized solar cells," Electrochimica Acta, vol. 56, no. 21, pp. 7256-7260, 2011.

[123] D. Gutiérrez-Tauste, I. Zumeta, E. Vigil, M. A. HernándezFenollosa, X. Domènech, and J. A. Ayllón, "New lowtemperature preparation method of the $\mathrm{TiO}_{2}$ porous photoelectrode for dye-sensitized solar cells using UV irradiation," Journal of Photochemistry and Photobiology A, vol. 175, no. 2-3, pp. 165-171, 2005.

[124] M. Tomoaki, M. Hideki, K. Toshiaki, and H. Yukie, "Outcome of nonpenetrating trabeculectomy for glaucoma," Japanese Journal of Clinical Ophthalmology, vol. 58, no. 2, pp. 187-191, 2004.

[125] T. Oekermann, D. Zhang, T. Yoshida, and H. Minoura, "Electron transport and back reaction in nanocrystalline $\mathrm{TiO}_{2}$ films prepared by hydrothermal crystallization," Journal of Physical Chemistry B, vol. 108, no. 7, pp. 2227-2235, 2004.

[126] T. Clark Jr., J. D. Ruiz, H. Fan, C. J. Brinker, B. I. Swanson, and A. N. Parikh, "A new application of UV-ozone treatment the preparation of substrate-supported, mesoporous thin films," Chemistry of Materials, vol. 12, no. 12, pp. 3879-3884, 2000.

[127] G. Mincuzzi, L. Vesce, A. Reale, A. Di Carlo, and T. M. Brown, "Efficient sintering of nanocrystalline titanium dioxide films for dye solar cells via raster scanning laser," Applied Physics Letters, vol. 95, no. 10, Article ID 103312, 2009.

[128] S. Uchida, M. Tomiha, H. Takizawa, and M. Kawaraya, "Flexible dye-sensitized solar cells by $28 \mathrm{GHz}$ microwave irradiation," Journal of Photochemistry and Photobiology A, vol. 164, no. 13, pp. 93-96, 2004. 
[129] X. Gan, X. Li, X. Gao, F. Zhuge, and W. Yu, “ZnO nanowire/ $\mathrm{TiO}_{2}$ nanoparticle photoanodes prepared by the ultrasonic irradiation assisted dip-coating method," Thin Solid Films, vol. 518, no. 17, pp. 4809-4812, 2010.

[130] H. Choi, H. Kim, S. Hwang, W. Choi, and M. Jeon, "Dyesensitized solar cells using graphene-based carbon nano composite as counter electrode," Solar Energy Materials and Solar Cells, vol. 95, no. 1, pp. 323-325, 2011.

[131] Y. J. Chen, Y. S. Lo, C. H. Huang, Y. C. Cai, and M. C. $\mathrm{Hsu}$, "Anode growth of DSSCs by flat-flame chemical vapor deposition method," Materials Chemistry and Physics, vol. 120, no. 1, pp. 181-186, 2010.

[132] K. E. Kim, S.-R. Jang, J. Park, R. Vittal, and K.-J. Kim, "Enhancement in the performance of dye-sensitized solar cells containing $\mathrm{ZnO}$-covered $\mathrm{TiO}_{2}$ electrodes prepared by thermal chemical vapor deposition," Solar Energy Materials and Solar Cells, vol. 91, no. 4, pp. 366-370, 2007.

[133] G.-Y. Zeng, K.-S. Nian, and K.-Y. Lee, "Characteristics of a dyesensitized solar cell based on an anode combining $\mathrm{ZnO}$ nanostructures with vertically aligned carbon nanotubes," Diamond and Related Materials, vol. 19, no. 12, pp. 1457-1460, 2010.

[134] J. Y. Roh, Y. H. Kim, and C. S. Lee, "Synthesis of MWNTs using thermal chemical vapor deposition for the application of a counter electrode for DSSCs," Current Applied Physics, vol. 11, no. 4, pp. S69-S72, 2011.

[135] S. H. Nam, J.-S. Hyun, and J.-H. Boo, "Synthesis of $\mathrm{TiO}_{2}$ thin films using single molecular precursors by MOCVD method for dye-sensitized solar cells application and study on film growth mechanism," Materials Research Bulletin, vol. 47, no. 10, pp. 2717-2721, 2012.

[136] T.-T. Wang, P. Raghunath, Y.-F. Lu, Y.-C. Liu, C.-H. Chiou, and M. C. Lin, "Observation of Significant enhancement in the efficiency of a DSSC by InN nanoparticles over $\mathrm{TiO}_{2}-$ nanoparticle films," Chemical Physics Letters, vol. 510, no. 1-3, pp. 126-130, 2011.

[137] S. Nejati and K. K. S. Lau, "Integration of polymer electrolytes in dye sensitized solar cells by initiated chemical vapor deposition," Thin Solid Films, vol. 519, no. 14, pp. 4551-4554, 2011.

[138] C. Quiñonez, W. Vallejo, and G. Gordillo, "Structural, optical and electrochemical properties of $\mathrm{TiO}_{2}$ thin films grown by APCVD method," Applied Surface Science, vol. 256, no. 13, pp. 4065-4071, 2010.

[139] P. S. Shinde and C. H. Bhosale, "Properties of chemical vapour deposited nanocrystalline $\mathrm{TiO}_{2}$ thin films and their use in dye-sensitized solar cells," Journal of Analytical and Applied Pyrolysis, vol. 82, no. 1, pp. 83-88, 2008.

[140] V. Ganapathy, B. Karunagaran, and S.-W. Rhee, "Improved performance of dye-sensitized solar cells with $\mathrm{TiO}_{2}$ /alumina core-shell formation using atomic layer deposition," Journal of Power Sources, vol. 195, no. 15, pp. 5138-5143, 2010.

[141] M. Shanmugam, M. F. Baroughi, and D. Galipeau, "Effect of atomic layer deposited ultra thin $\mathrm{HfO}_{2}$ and $\mathrm{Al}_{2} \mathrm{O}_{3}$ interfacial layers on the performance of dye sensitized solar cells," Thin Solid Films, vol. 518, no. 10, pp. 2678-2682, 2010.

[142] T.-C. Tien, F.-M. Pan, L.-P. Wang, F. Y. Tsai, and C. Lin, "Growth mode transition of atomic layer deposited $\mathrm{Al}_{2} \mathrm{O}_{3}$ on porous $\mathrm{TiO}_{2}$ electrodes of dye-sensitized solar cells," Thin Solid Films, vol. 520, no. 6, pp. 1745-1750, 2012.

[143] J. Lee, K. S. Hong, K. Shin, and J. Y. Jho, "Fabrication of dye-sensitized solar cells using ordered and vertically oriented $\mathrm{TiO}_{2}$ nanotube arrays with open and closed ends," Journal of
Industrial and Engineering Chemistry, vol. 18, no. 1, pp. 19-23, 2012.

[144] J. Du, F. Bittner, D. S. Hecht et al., "A carbon nanotubesbased transparent conductive substrate for flexible $\mathrm{ZnO}$ dyesensitized solar cells," Thin Solid Films, vol. 531, pp. 391-397, 2013.

[145] R. Ranjusha, P. Lekha, K. R. V. Subramanian, V. N. Shantikumar, and A. Balakrishnan, "Photoanode activity of $\mathrm{ZnO}$ nanotube based dye-sensitized solar cells," Journal of Materials Science and Technology, vol. 27, no. 11, pp. 961-966, 2011.

[146] X. Gan, X. Li, X. Gao, X. He, and F. Zhuge, “Deposition potential dependence of $\mathrm{ZnO}$-eosin $\mathrm{Y}$ hybrid thin films prepared by electrochemical deposition and their photoelectrochemical properties," Materials Chemistry and Physics, vol. 114, no. 2-3, pp. 920-925, 2009.

[147] J. Elias, M. Parlinska-Wojtan, R. Erni et al., "Passing the limit of electrodeposition: "gas template" $\mathrm{H}_{2}$ nanobubbles for growing highly crystalline nanoporous ZnO," Nano Energy, vol. 1, no. 5, pp. 742-750, 2012.

[148] T. Yoshida, M. Iwaya, H. Ando et al., "Improved photoelectrochemical performance of electrodeposited $\mathrm{ZnO} /$ Eosin Y hybrid thin films by dye re-adsorption," Chemical Communications, vol. 10, no. 4, pp. 400-401, 2004.

[149] C. Lin, H. Lin, J. Li, and X. Li, "Electrodeposition preparation of $\mathrm{ZnO}$ nanobelt array films and application to dye-sensitized solar cells," Journal of Alloys and Compounds, vol. 462, no. 1-2, pp. 175-180, 2008.

[150] H.-W. Chen, C.-Y. Lin, Y.-H. Lai et al., "Electrophoretic deposition of $\mathrm{ZnO}$ film and its compression for a plastic based flexible dye-sensitized solar cell," Journal of Power Sources, vol. 196, no. 10, pp. 4859-4864, 2011.

[151] X. Yin, X. Liu, L. Wang, and B. Liu, "Electrophoretic deposition of $\mathrm{ZnO}$ photoanode for plastic dye-sensitized solar cells," Electrochemistry Communications, vol. 12, no. 9, pp. 1241-1244, 2010.

[152] Y.-T. Kim, J. Park, S. Kim, D. W. Park, and J. Choi, "Fabrication of hierarchical $\mathrm{ZnO}$ nanostructures for dye-sensitized solar cells," Electrochimica Acta, vol. 78, pp. 417-421, 2012.

[153] J. Qiu, M. Guo, Y. Feng, and X. Wang, "Electrochemical deposition of branched hierarchical $\mathrm{ZnO}$ nanowire arrays and its photoelectrochemical properties," Electrochimica Acta, vol. 56, no. 16, pp. 5776-5782, 2011.

[154] C. H. Yoon, R. Vittal, J. Lee, W.-S. Chae, and K.-J. Kim, "Enhanced performance of a dye-sensitized solar cell with an electrodeposited-platinum counter electrode," Electrochimica Acta, vol. 53, no. 6, pp. 2890-2896, 2008.

[155] G. Yue, J. Wu, Y. Xiao et al., "Platinum/graphene hybrid film as a counter electrode for dye-sensitized solar cells," Electrochimica Acta, vol. 92, pp. 64-70, 2013.

[156] G. H. Guai, Q. L. Song, C. X. Guo et al., "GraphenePtITO counter electrode to significantly reduce Pt loading and enhance charge transfer for high performance dye-sensitized solar cell," Solar Energy, vol. 86, no. 7, pp. 2041-2048, 2012.

[157] P. Li, J. Wu, J. Lin, M. Huang, Z. Lan, and Q. Li, "Improvement of performance of dye-sensitized solar cells based on electrodeposited-platinum counter electrode," Electrochimica Acta, vol. 53, no. 12, pp. 4161-4166, 2008.

[158] C.-C. Yang, H. Q. Zhang, and Y. R. Zheng, "DSSC with a novel Pt counter electrodes using pulsed electroplating techniques," Current Applied Physics, vol. 11, no. 1, pp. S147-S153, 2011. 
[159] X. Yin, Z. Xue, and B. Liu, "Electrophoretic deposition of Pt nanoparticles on plastic substrates as counter electrode for flexible dye-sensitized solar cells," Journal of Power Sources, vol. 196, no. 4, pp. 2422-2426, 2011.

[160] C.-M. Chen, C.-H. Chen, S.-J. Cherng, and T.-C. Wei, “Electroless deposition of platinum on indium tin oxide glass as the counterelectrode for dye-sensitized solar cells," Materials Chemistry and Physics, vol. 124, no. 1, pp. 173-178, 2010.

[161] M.-H. Yeh, C.-P. Lee, L.-Y. Lin et al., "A composite poly(3,3diethyl-3,4-dihydro-2H-thieno-[3,4-b][1,4]-dioxepine) and $\mathrm{Pt}$ film as a counter electrode catalyst in dye-sensitized solar cells," Electrochimica Acta, vol. 56, no. 17, pp. 6157-6164, 2011.

[162] T.-Y. Tsai and S.-Y. Lu, "A novel way of improving light harvesting in dye-sensitized solar cells-electrodeposition of titania," Electrochemistry Communications, vol. 11, no. 11, pp. 2180-2183, 2009.

[163] Y.-L. Xie, Z.-X. Li, Z.-G. Xu, and H.-L. Zhang, "Preparation of coaxial $\mathrm{TiO}_{2} / \mathrm{ZnO}$ nanotube arrays for high-efficiency photoenergy conversion applications," Electrochemistry Communications, vol. 13, no. 8, pp. 788-791, 2011.

[164] S. Sakurai, H.-Q. Jiang, M. Takahashi, and K. Kobayashi, "Enhanced performance of a dye-sensitized solar cell with a modified poly(3,4-ethylenedioxythiophene)/ $\mathrm{TiO}_{2} / \mathrm{FTO}$ counter electrode," Electrochimica Acta, vol. 54, no. 23, pp. 5463-5469, 2009.

[165] H.-J. An, S.-R. Jang, R. Vittal, J. Lee, and K.-J. Kim, “Cationic surfactant promoted reductive electrodeposition of nanocrystalline anatase $\mathrm{TiO}_{2}$ for application to dye-sensitized solar cells," Electrochimica Acta, vol. 50, no. 13, pp. 2713-2718, 2005.

[166] K. Wessels, M. Maekawa, J. Rathousky, and T. Oekermann, "One-step electrodeposition of $\mathrm{TiO}_{2} /$ dye hybrid films," Thin Solid Films, vol. 515, no. 16, pp. 6497-6500, 2007.

[167] L. Zhao, J. Yu, J. Fan, P. Zhai, and S. Wang, "Dye-sensitized solar cells based on ordered titanate nanotube films fabricated by electrophoretic deposition method," Electrochemistry Communications, vol. 11, no. 10, pp. 2052-2055, 2009.

[168] G.-S. Kim, H.-K. Seo, V. P. Godble, Y.-S. Kim, O. B. Yang, and H.-S. Shin, "Electrophoretic deposition of titanate nanotubes from commercial titania nanoparticles: application to dyesensitized solar cells," Electrochemistry Communications, vol. 8, no. 6, pp. 961-966, 2006.

[169] H.-W. Chen, K.-C. Huang, C.-Y. Hsu et al., "Electrophoretic deposition of $\mathrm{TiO}_{2}$ film on titanium foil for a flexible dyesensitized solar cell," Electrochimica Acta, vol. 56, no. 23, pp. 7991-7998, 2011.

[170] H.-W. Chen, C.-Y. Hsu, J.-G. Chen et al., "Plastic dye-sensitized photo-supercapacitor using electrophoretic deposition and compression methods," Journal of Power Sources, vol. 195, no. 18, pp. 6225-6231, 2010.

[171] C.-C. Tsai, Y.-Y. Chu, and H. Teng, "A simple electrophoretic deposition method to prepare $\mathrm{TiO}_{2}-\mathrm{B}$ nanoribbon thin films for dye-sensitized solar cells," Thin Solid Films, vol. 519, no. 2, pp. $662-665,2010$.

[172] S. Wang, J. Zhang, S. Chen et al., "Conversion enhancement of flexible dye-sensitized solar cells based on $\mathrm{TiO}_{2}$ nanotube arrays with $\mathrm{TiO}_{2}$ nanoparticles by electrophoretic deposition," Electrochimica Acta, vol. 56, no. 17, pp. 6184-6188, 2011.

[173] M. Chigane and T. Shinagawa, "Titanium dioxide thin films prepared by electrolysis from aqueous solution of titaniumlactic acid complex for dye-sensitized solar cells," Thin Solid Films, vol. 520, no. 9, pp. 3510-3514, 2012.
[174] P.-J. Chu, S.-Y. Wu, K.-C. Chen, J.-L. He, A. Yerokhin, and A. Matthews, "Nano-structured $\mathrm{TiO}_{2}$ films by plasma electrolytic oxidation combined with chemical and thermal posttreatments of titanium, for dye-sensitised solar cell applications," Thin Solid Films, vol. 519, no. 5, pp. 1723-1728, 2010.

[175] D. Zheng, M. Lv, S. Wang, W. Guo, L. Sun, and C. Lin, "A combined $\mathrm{TiO}_{2}$ structure with nanotubes and nanoparticles for improving photoconversion efficiency in dye-sensitized solar cells," Electrochimica Acta, vol. 83, pp. 155-159, 2012.

[176] H. Wang, H. Li, J. Wang, and J. Wu, "High aspect-ratio transparent highly ordered titanium dioxide nanotube arrays and their performance in dye sensitized solar cells," Materials Letters, vol. 80, pp. 99-102, 2012.

[177] E. Tsuji, N. Hirata, Y. Aoki, and H. Habazaki, "Preparation of non-annealed anatase $\mathrm{TiO}_{2}$ film on ITO substrate by anodizing in hot phosphate/glycerol electrolyte for dye-sensitized solar cells," Materials Letters, vol. 91, pp. 39-41, 2013.

[178] L. Sun, S. Zhang, X. W. Sun, and X. He, "Effect of electric field strength on the length of anodized titania nanotube arrays," Journal of Electroanalytical Chemistry, vol. 637, no. 1-2, pp. 612, 2009.

[179] Q. Pang, L. Leng, L. Zhao, L. Zhou, C. Liang, and Y. Lan, "Dye sensitized solar cells using freestanding $\mathrm{TiO}_{2}$ nanotube arrays on FTO substrate as photoanode," Materials Chemistry and Physics, vol. 125, no. 3, pp. 612-616, 2011.

[180] H. Jha, P. Roy, R. Hahn, I. Paramasivam, and P. Schmuki, "Fast formation of aligned high-aspect ratio $\mathrm{TiO}_{2}$ nanotube bundles that lead to increased open circuit voltage when used in dye sensitized solar cells," Electrochemistry Communications, vol. 13, no. 3, pp. 302-305, 2011.

[181] H. Y. Hwang, A. A. Prabu, D. Y. Kim, and K. J. Kim, "Influence of the organic electrolyte and anodization conditions on the preparation of well-aligned $\mathrm{TiO}_{2}$ nanotube arrays in dyesensitized solar cells," Solar Energy, vol. 85, no. 7, pp. 1551-1559, 2011.

[182] C.-H. Chen, K.-C. Chen, and J.-L. He, "Transparent conducting oxide glass grown with $\mathrm{TiO}_{2}$-nanotube array for dye-sensitized solar cell," Current Applied Physics, vol. 10, no. 2, pp. S176-S179, 2010.

[183] S. Wang, X. Wu, W. Qin, and Z. Jiang, “ $\mathrm{TiO}_{2}$ films prepared by micro-plasma oxidation method for dye-sensitized solar cell," Electrochimica Acta, vol. 53, no. 4, pp. 1883-1889, 2007.

[184] T. Hino, Y. Ogawa, and N. Kuramoto, "Preparation of functionalized and non-functionalized fullerene thin films on ITO glasses and the application to a counter electrode in a dyesensitized solar cell," Carbon, vol. 44, no. 5, pp. 880-887, 2006.

[185] Z. Chen, Y. Tian, S. Li, H. Zheng, and W. Zhang, "Electrodeposition of arborous structure nanocrystalline $\mathrm{SnO}_{2}$ and application in flexible dye-sensitized solar cells," Journal of Alloys and Compounds, vol. 515, pp. 57-62, 2012.

[186] Y. Selk, T. Yoshida, and T. Oekermann, "Variation of the morphology of electrodeposited copper thiocyanate films," Thin Solid Films, vol. 516, no. 20, pp. 7120-7124, 2008.

[187] K.-M. Lee, P.-Y. Chen, C.-Y. Hsu et al., "A high-performance counter electrode based on poly(3,4-alkylenedioxythiophene) for dye-sensitized solar cells," Journal of Power Sources, vol. 188, no. 1, pp. 313-318, 2009.

[188] K. Okada, H. Matsui, T. Kawashima, T. Ezure, and N. Tanabe, "100 mm $\times 100 \mathrm{~mm}$ large-sized dye sensitized solar cells," Journal of Photochemistry and Photobiology A, vol. 164, no. 1-3, pp. 193-198, 2004. 
[189] J. Chen, B. Li, J. Zheng, J. Zhao, H. Jing, and Z. Zhu, "Polyaniline nanofiber/carbon film as flexible counter electrodes in platinum-free dye-sensitized solar cells," Electrochimica Acta, vol. 56, no. 12, pp. 4624-4630, 2011.

[190] Y. Xiao, J.-Y. Lin, W.-Y. Wang, S.-Y. Tai, G. Yue, and J. Wu, "Enhanced performance of low-cost dye-sensitized solar cells with pulse-electropolymerized polyaniline counter electrodes," Electrochimica Acta, vol. 90, pp. 468-474, 2013.

[191] T. Kawashima, T. Ezure, K. Okada, H. Matsui, K. Goto, and N. Tanabe, "FTO/ITO double-layered transparent conductive oxide for dye-sensitized solar cells," Journal of Photochemistry and Photobiology A, vol. 164, no. 1-3, pp. 199-202, 2004.

[192] K. Goto, T. Kawashima, and N. Tanabe, "Heat-resisting TCO films for PV cells," Solar Energy Materials and Solar Cells, vol. 90, no. 18-19, pp. 3251-3260, 2006.

[193] S. Katusic, P. Albers, R. Kern et al., "Production and characterization of ITO-Pt semiconductor powder containing nanoscale noble metal particles catalytically active in dye-sensitized solar cells," Solar Energy Materials and Solar Cells, vol. 90, no. 13, pp. 1983-1999, 2006.

[194] C. Jiang, M. Y. Leung, W. L. Koh, and Y. Li, "Influences of deposition and post-annealing temperatures on properties of $\mathrm{TiO}_{2}$ blocking layer prepared by spray pyrolysis for solid-state dye-sensitized solar cells," Thin Solid Films, vol. 519, no. 22, pp. 7850-7854, 2011.

[195] C. Jiang, W. L. Koh, M. Y. Leung, W. Hong, Y. Li, and J. Zhang, "Influences of alcoholic solvents on spray pyrolysis deposition of $\mathrm{TiO}_{2}$ blocking layer films for solid-state dye-sensitized solar cells," Journal of Solid State Chemistry, vol. 198, pp. 197-202, 2013.

[196] M. Okuya, K. Nakade, and S. Kaneko, "Porous $\mathrm{TiO}_{2}$ thin films synthesized by a spray pyrolysis deposition (SPD) technique and their application to dye-sensitized solar cells," Solar Energy Materials and Solar Cells, vol. 70, no. 4, pp. 425-435, 2002.

[197] H. M. N. Bandara, R. M. G. Rajapakse, K. Murakami, G. R. R. A. Kumara, and G. A. Sepalage, "Dye-sensitized solar cell based on optically transparent $\mathrm{TiO}_{2}$ nanocrystalline electrode prepared by atomized spray pyrolysis technique," Electrochimica Acta, vol. 56, no. 25, pp. 9159-9161, 2011.

[198] J. Xia, N. Masaki, K. Jiang, and S. Yanagida, "Fabrication and characterization of thin $\mathrm{Nb}_{2} \mathrm{O}_{5}$ blocking layers for ionic liquidbased dye-sensitized solar cells," Journal of Photochemistry and Photobiology A, vol. 188, no. 1, pp. 120-127, 2007.

[199] B. N. Pawar, G. Cai, D. Ham et al., "Preparation of transparent and conducting boron-doped $\mathrm{ZnO}$ electrode for its application in dye-sensitized solar cells," Solar Energy Materials and Solar Cells, vol. 93, no. 4, pp. 524-527, 2009.

[200] V. Dutta, "Spray deposited $\mathrm{ZnO}$ nanostructured layers for dye sensitized solar cells," Energy Procedia, vol. 3, pp. 58-62, 2011.

[201] N. Alexaki, T. Stergiopoulos, A. G. Kontos et al., "Mesoporous titania nanocrystals prepared using hexadecylamine surfactant template: crystallization progress monitoring, morphological characterization and application in dye-sensitized solar cells," Microporous and Mesoporous Materials, vol. 124, no. 1-3, pp. 52$58,2009$.

[202] Y. Zhang, Z. Xie, and J. Wang, "Pre-curing of supramoleculartemplated mesoporous $\mathrm{TiO}_{2}$ films for dye-sensitized solar cells," Thin Solid Films, vol. 518, no. 24, pp. e34-e37, 2010.

[203] S. Ngamsinlapasathian, S. Pavasupree, Y. Suzuki, and S. Yoshikawa, "Dye-sensitized solar cell made of mesoporous titania by surfactant-assisted templating method," Solar Energy Materials and Solar Cells, vol. 90, no. 18-19, pp. 3187-3192, 2006.
[204] K.-J. Hwang, W.-G. Shim, S.-H. Jung, S.-J. Yoo, and J.-W. Lee, "Analysis of adsorption properties of N719 dye molecules on nanoporous $\mathrm{TiO}_{2}$ surface for dye-sensitized solar cell," Applied Surface Science, vol. 256, no. 17, pp. 5428-5433, 2010.

[205] X. P. Lin, D. M. Song, X. Q. Gu, Y. L. Zhao, and Y. H. Qiang, "Synthesis of hollow spherical $\mathrm{TiO}_{2}$ for dye-sensitized solar cells with enhanced performance," Applied Surface Science, vol. 263, pp. 816-820, 2012.

[206] T. K. Yun, S. S. Park, D. Kim et al., "Pore-size effect on photovoltaic performance of dye-sensitized solar cells composed of mesoporous anatase-titania," Journal of Power Sources, vol. 196, no. 7, pp. 3678-3682, 2011.

[207] Y. Liu, S. Wang, Z. Shan et al., "Anatase $\mathrm{TiO}_{2}$ hollow spheres with small dimension fabricated via a simple preparation method for dye-sensitized solar cells with an ionic liquid electrolyte," Electrochimica Acta, vol. 60, pp. 422-427, 2012.

[208] H. Li, Y. Zhou, C. Lv, and M. Dang, “Templated synthesis of ordered porous $\mathrm{TiO}_{2}$ films and their application in dyesensitized solar cell," Materials Letters, vol. 65, no. 12, pp. 18081810, 2011.

[209] C.-C. Han, S.-Y. Ho, Y.-P. Lin, Y.-C. Lai, W.-C. Liang, and Y. W. Chen-Yang, "Effect of $\pi-\pi$ stacking of water miscible ionic liquid template with different cation chain length and content on morphology of mesoporous $\mathrm{TiO}_{2}$ prepared via solgel method and the applications," Microporous and Mesoporous Materials, vol. 131, no. 1-3, pp. 217-223, 2010.

[210] L. Qi and D. P. Birnie III, “Templated titania films with mesoand macroporosities," Materials Letters, vol. 61, no. 11-12, pp. 2191-2194, 2007.

[211] Y. Fu, Z. Jin, Y. Ni, H. Du, and T. Wang, "Microstructure, optical and optoelectrical properties of mesoporous nc- $\mathrm{TiO}_{2}$ films by hydrolysis-limited sol-gel process with different inhibitors," Thin Solid Films, vol. 517, no. 19, pp. 5634-5640, 2009.

[212] Z. Liu, C. Liu, J. Ya, and E. Lei, "Controlled synthesis of $\mathrm{ZnO}$ and $\mathrm{TiO}_{2}$ nanotubes by chemical method and their application in dye-sensitized solar cells," Renewable Energy, vol. 36, no. 4, pp. 1177-1181, 2011.

[213] E. Ramasamy and J. Lee, "Ferrocene-derivatized ordered mesoporous carbon as high performance counter electrodes for dyesensitized solar cells," Carbon, vol. 48, no. 13, pp. 3715-3720, 2010.

[214] E. Ramasamy, J. Chun, and J. Lee, "Soft-template synthesized ordered mesoporous carbon counter electrodes for dyesensitized solar cells," Carbon, vol. 48, no. 15, pp. 4563-4565, 2010.

[215] S.-H. Park, H.-R. Jung, B.-K. Kim, and W.-J. Lee, "MWCNT/ mesoporous carbon nanofibers composites prepared by electrospinning and silica template as counter electrodes for dyesensitized solar cells," Journal of Photochemistry and Photobiology A, vol. 246, pp. 45-49, 2012.

[216] S. Sumikura, S. Mori, S. Shimizu, H. Usami, and E. Suzuki, "Syntheses of $\mathrm{NiO}$ nanoporous films using nonionic triblock copolymer templates and their application to photo-cathodes of p-type dye-sensitized solar cells," Journal of Photochemistry and Photobiology A, vol. 199, no. 1, pp. 1-7, 2008.

[217] N. Sharifi, S. Dadgostar, N. Taghavinia, and A. Iraji zad, "Freestanding light scattering hollow silver spheres prepared by a facile sacrificial templating method and their application in dye-sensitized solar cells," Journal of Power Sources, vol. 225, pp. 46-50, 2013. 

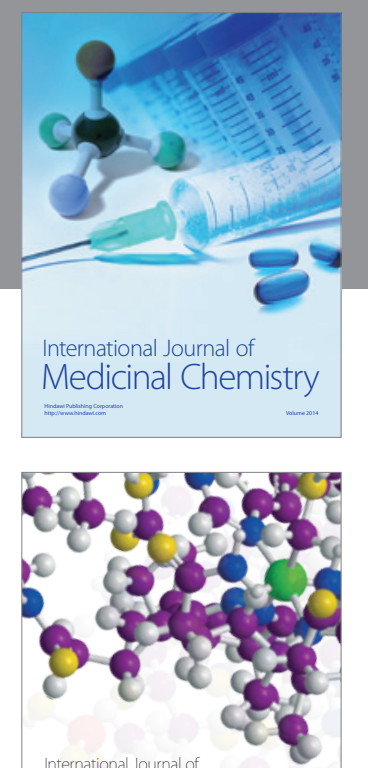

\section{Carbohydrate} Chemistry

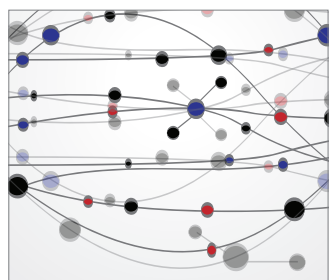

The Scientific World Journal
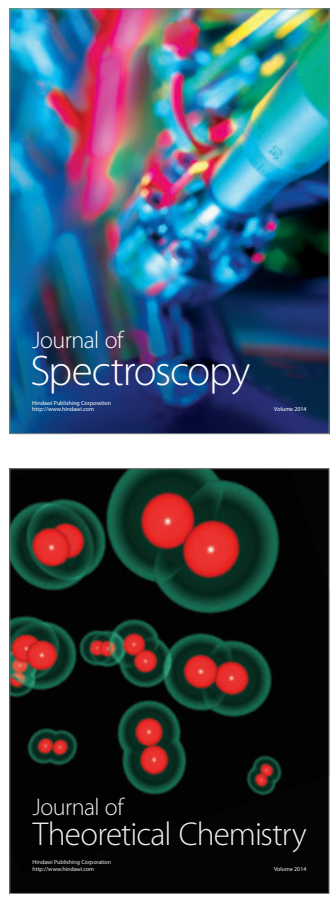
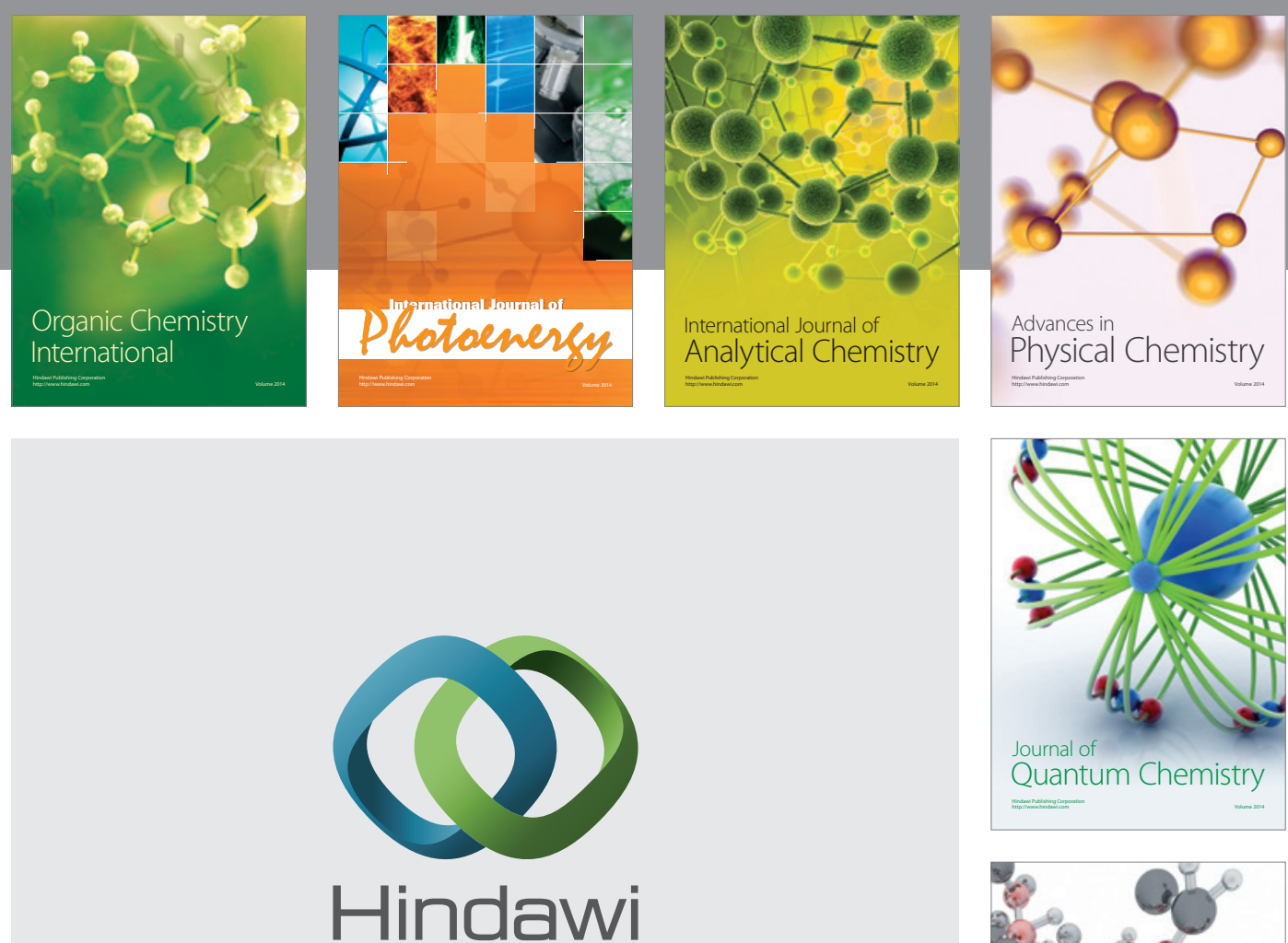

Submit your manuscripts at

http://www.hindawi.com

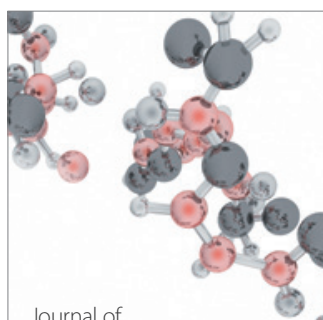

Analytical Methods

in Chemistry

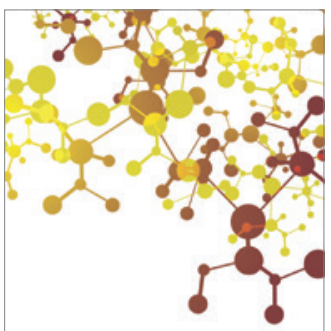

Journal of

Applied Chemistry

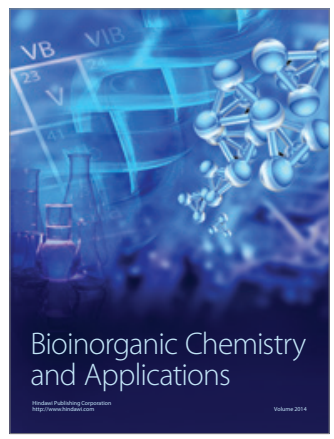

Inorganic Chemistry
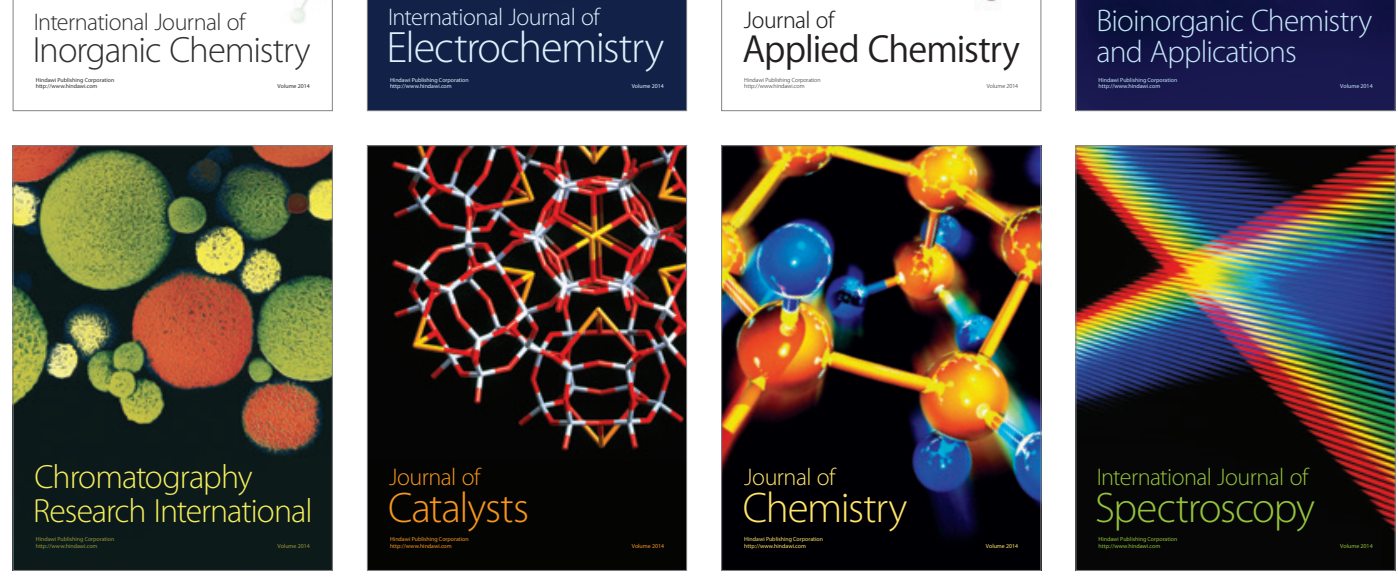